\title{
Model-based study of the role of rainfall and land use-land cover in the changes in the occurrence and intensity of Niger red floods in Niamey between 1953 and 2012
}

\author{
Claire Casse $^{1}$, Marielle Gosset ${ }^{1}$, Théo Vischel ${ }^{2}$, Guillaume Quantin ${ }^{2}$, and Bachir Alkali Tanimoun ${ }^{3}$ \\ ${ }^{1}$ Géoscience Environnement Toulouse (UMR5563 CNRS, IRD, Université Toulouse III), Observatoire Midi-Pyrénées, \\ Toulouse, France \\ ${ }^{2}$ Laboratoire des Transferts en Hydrologie et Environnement (UMR5564, CNRS, IRD, Université Grenoble I), France \\ ${ }^{3}$ Autorité du Bassin du Niger (ABN), Niamey, Niger
}

Correspondence to: Claire Casse (claire.casse@get.obs-mip.fr) and Marielle Gosset (marielle.gosset@ird.fr)

Received: 2 October 2015 - Published in Hydrol. Earth Syst. Sci. Discuss.: 18 November 2015

Revised: 7 April 2016 - Accepted: 9 May 2016 - Published: 15 July 2016

\begin{abstract}
Since 1950, the Niger River basin has gone through three main climatic periods: a wet period (19501960), an extended drought (1970-1980) and since 1990 a recent partial recovery of annual rainfall. Hydrological changes co-occur with these rainfall fluctuations. In most of the basin, the rainfall deficit caused an enhanced discharge deficit, but in the Sahelian region the runoff increased despite the rainfall deficit. Since 2000 the Sahelian part of the Niger has been hit by an increase of flood hazards during the so-called red flood period. In Niamey city, the highest river levels and the longest flooded period ever recorded occurred in 2003, 2010, 2012 and 2013, with heavy casualties and property damage. The reasons for these changes, and the relative role of climate versus land use-land cover (LULC) changes are still debated and are investigated in this paper. The evolution of the Niger red flood in Niamey from 1950 to 2012 is analysed based on long-term records of rainfall (three data sets based on in situ and/or satellite data) and discharge, and a hydrological model. The model is first run with the present LULC conditions in order to analyse solely the effect of rainfall variability. The impact of LULC and drainage area modification is investigated in a second step. The simulations based on the current surface conditions are able to reproduce the observed trend in the red flood occurrence and intensity since the 1980s. This has been verified with three independent rainfall data sets and implies that rainfall variability is the main driver for the red flood intensification observed over the last 30 years. The simulation results since 1953 have revealed
\end{abstract}

that LULC and drainage area changes need to be invoked to explain the changes over a 60 -year period.

\section{Introduction}

The Sahel region has overcome drastic changes over the last 60 years. The long drought that occurred in the 1970s and 1980s (Lamb, 1982; Le Barbé and Lebel, 1997; Nicholson et al., 2000; Camberin et al., 2002; Le Barbé et al., 2002; L'Hôte et al., 2002; Dai et al., 2004; Lebel and Ali, 2009; Panthou et al., 2014) is considered to be one of the strongest climatic signals of the 20th century (L'Hôte et al., 2002; Dai et al., 2004; Narisma et al., 2007). In addition to dramatic consequences on the population, this drought induced long-term changes on the eco- and hydrosystems. Since the 1990s the region has come back to wetter conditions even though the annual rainfall is not back to the levels reached in the 1950s or 1960s. This recent partial recovery is heterogeneous over the Sahel, with dry conditions persisting in the western part (Nicholson et al., 2000; L'Hôte et al., 2002; Dia et al., 2004; Lebel and Ali, 2009; Panthou et al., 2014). In the central-eastern Sahel the rainfall deficit is dropping over the last decade, inter-annual variability is strong (Dai et al., 2004) and rainfall appears more intense (more extreme events) than in the 1950s and 1960s (Panthou et al., 2014).

Concurrent with these climatic variations West Africa has experienced major hydrological changes. The Niger (Fig. 1) 


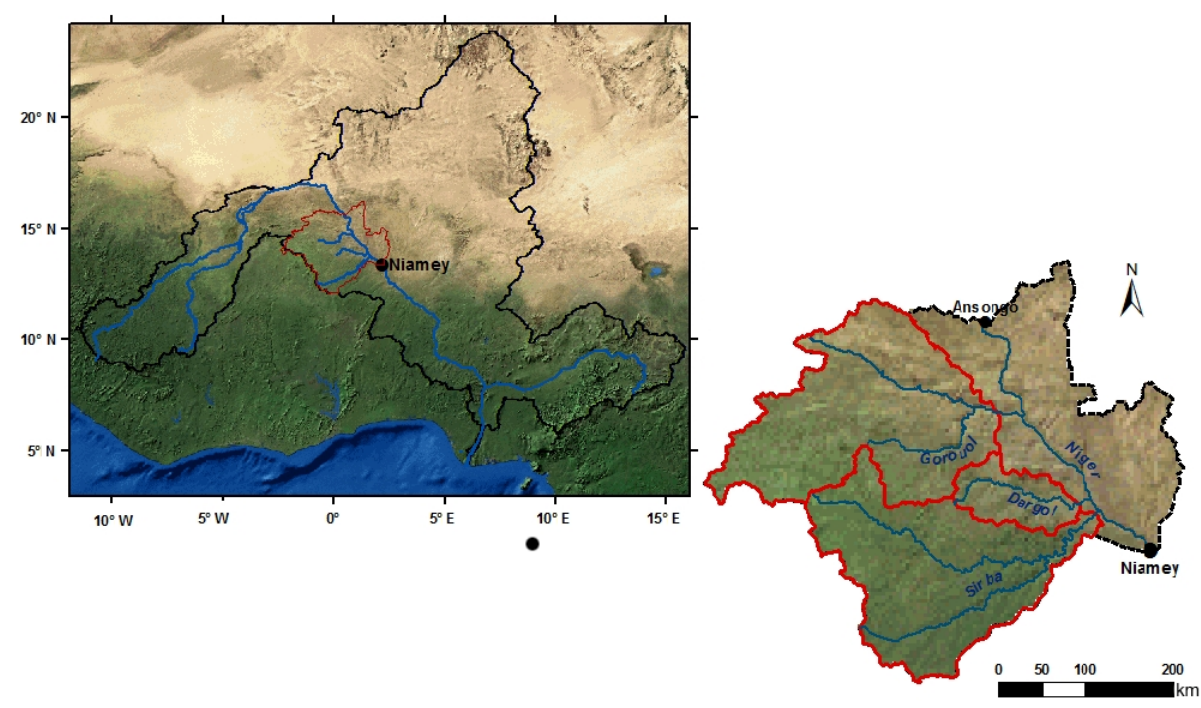

Figure 1. Map of the Niger basin (top left) and the zoomed in image of the Ansongo-Niamey reach basin (bottom right). The red contours on the bottom right plots delineate the three main tributaries contributing to the red flood (C. Casse and L. Gal, based on SIEREM and NOAA database).

is the largest river of West Africa and goes through a strong climatic gradient from the humid Guinean region to the subdesertic Sahara and through the semi-arid Sahel. The hydrological response to the extended drought of the 1970s1980s has been different in the various sub-regions of the Niger basin. In the Guinean region the discharge deficit was twice as important as the rainfall deficit (Briquet et al., 1996; Mahé et al., 2000; Mahé, 2009; Paturel et al., 2010). After the 1970s-1980s the discharge deficit of the Bani (the main tributary of the upper Niger River) compared to the 1950s reached $80 \%$ (Mahé et al., 2000). During the same dry years the phenomenon know as "Sahelian paradox" (Descroix et al., 2009) was observed in many part of the Sahel: an increase in runoff despite the deficit in rainfall (Albergel, 1987; Amani and Nguetora, 2002; Mahé et al., 2003, 2005; Mahé and Paturel, 2009). This phenomenon resulted from a discharge increase in exorheic ${ }^{1}$ basins (Amani and Nguetora, 2002; Mahé et al., 2003, 2005; Mahé and Paturel, 2009; Descroix et al., 2009; Amogu et al., 2010) and in larger pond surfaces, infiltration and water table levels in the endorheic ${ }^{2}$ areas (Desconnet et al., 1997; Leduc et al., 2001; Favreau et al., 2009; Gardelle et al., 2010).

The discharge of the Niger River in Niamey (Fig. 1), the capital city of Niger, is impacted by the hydrological behaviour of both the upper Niger basin and of the Sahelian tributaries. The rainfall in the upper Niger triggers the Guinean flood, which propagates slowly and occurs in Niamey after the rainy season (around January) (Millot, 1913; Pardé, 1933; Descroix et al., 2012; Sighomnou et al., 2013).

\footnotetext{
${ }^{1}$ where the hydrographic network connects to a river and or to the ocean

2 where the hydrographic network does not connect to a river
}

The rainfall drained by the Sahelian tributaries in the vicinity of Niamey superimposes on the Niger River flows and triggers the red flood; red refers to the colour of the water loaded in iron oxide sediment during this period (Millot, 1913; Pardé, 1933; Descroix et al., 2012; Sighomnou et al., 2013). Before the rainfall deficit of the 1970s-1980s the hydrograph in Niamey had a single peak; the red flood was low and almost merged with the Guinean flood. Gradually after the 1970s-1980s, the runoff increased in the Sahelian tributaries and enhanced their contribution to the red flood. Consequently, the hydrograph in Niamey evolved from a "one peak" to a "two peaks" shape (Amani and Nguetora, 2002; Mahé et al., 2003; Amogu et al., 2010; Sighomnou et al., 2013). Descroix et al. (2012) poetically described this phenomenon as "the dromedary became a camel". The increasing intensity of the red flood in the last decade has enhanced the inundation risk, causing dramatic human and material losses. In 2003, 2010, 2012 and 2013 water levels and duration of the inundation were the highest ever recorded since the beginning of observations in 1920 (Sighomnou et al., 2013).

The reasons for this dramatic increase in the flood risk in Niamey are still debated by the scientific community. Previous studies, based on observations only, have shown the correlation between the drastic changes in the surface and vegetation conditions in Sahelian sub-basins and the changes in their hydrological behaviour, like an increase in runoff. These processes have been proposed as an explanation for the observed changes in Niamey's hydrograph. In Sahel, runoff is mainly controlled by surface conditions (Collinet et Valentin, 1979; Albergel et al., 1987; Cazenave et Valentin, 1992), which have been changing under climatic 
(Hiernaux and Le Houérou, 2006; Leblanc et al., 2008) and anthropic pressure - wood harvesting (Peltier et al., 1995; Leblanc et al., 2008) or crop extension (Valentin et al., 2004). Several authors (Amani and Nguetora, 2002; Mahé et al., 2003; Leblanc et al., 2008; Amogu et al., 2010; Descroix et al., 2009, 2012, 2013) have highlighted that hydrological changes in Niamey hydrograph could be triggered by the land use-land cover (LULC) changes (and the resulting runoff increase) that have occurred since the 1970s in the three main tributaries of the Niger responsible for the red flood in Niamey (the Gorouol, Dargol and Sirba rivers). Recently small-scale changes in the hydrographical network in the vicinity of Niamey have been put forward as a possible driver for red flood increase (Amogu et al., 2010; Descroix et al., 2012; Mamadou et al., 2015). In some parts of the Niger left bank, which used not to contribute to the river (endorheism), heavy runoff has increased the network connection (Leblanc et al., 2008; Amogu et al., 2010) and opened new water channels to the main river. The role of a changing rainfall regime in the flood risk increase is also an open question (Nka et al., 2015). Recent studies suggest that rainfall has intensified in the central Sahel (Panthou et al, 2014). In a region where the runoff is very dependent on high rainfall intensities (Vischel and Lebel, 2007; Casse et al., 2015), a strong hydrological response to rainfall extremes is expected. The present paper does not intend to provide new evidence about these changes but rather to investigate their impact on the hydrological regime. The interactions and co-occurrence of the LULC, water pathway and rainfall changes over the past decades make it difficult to attribute the flood risk increase on the basis of observations alone. Unlike the intricate reality, models allow for testing the influences of each process or variable independently. Many authors have used hydrological modelling (based on different scale, basin, data set and model) to infer the role of climate and LULC on hydrological changes in West Africa since 1950 (1950-1998: Seguis et al., 2004, 1951-2000: D'Orgeval and Polcher, 2008, 1950-2009: Aich et al., 2015). The conclusions differ among these studies: D'Orgeval and Polcher (2008) found that LULC was less important than rainfall changes, in contrast to Seguis et al. (2004), while Aich et al. (2015) concluded on the role of both LULC and climate. Casse and Gosset (2015) presented a preliminary work between 1983 and 2012, and showed that rainfall variability alone could explain the observed changes in the Niger River hydrograph in Niamey over the last 30 years. Only Aich et al. (2015) and Casse and Gosset (2015) focused on the Sahelian tributaries of the Niger and the Niamey station. Both studies based their conclusion on one rainfall data set, Aich et al. (2015) used a re-analysis product and Casse and Gosset (2015) a satellite rainfall product (PERSIANN-CDR - Precipitation Estimation from Remotely Sensed Information using Artificial Neural Network - Climate Data Record, Ashouri et al., 2015).
Following the preliminary work of Casse and Gosset (2015), this paper aims to better understand the role of the three main identified environmental changes that could drive the hydrological evolution of the Niamey red flood from 1950 to 2012. This study is based on long-term records of rainfall and discharge, and a hydrological model. It investigates the sensitivity of the hydrological response to rainfall variability, LULC and drainage area changes. The model is first run with the present LULC and drainage area conditions in order to analyse solely the effect of rainfall variability. The impact of LULC and drainage area modification is investigated in a second step. The numerical experiment is first carried out over the 1983-2012 period, where three different rainfall products are available to verify that conclusions on the role of rainfall changes are robust and independent of the data set. The changes since 1950 are then analysed using the only data set available for the extended period (based on rain gauges). The originality of this paper compared to previous studies lies in (i) the time period that includes the 2010 and 2012 record red floods, (ii) the various rainfall products used, (iii) the study of the basin area changes (iv) and the decadal approach to analyse the long-term changes.

Section 2 describes the study area, the data and the hydrological model set-up. Section 3 presents the observed changes in rainfall and discharge over 1950-2012. Section 4 analyses the hydrological model outputs, compares the simulated and observed changes over the 6 decades, and discusses the sensitivity to LULC and drainage area changes. Section 5 gives the conclusions about the role of rainfall variability and other drivers of change in the increase of the red flood events since the 1950s.

\section{Data and method}

\subsection{Study area and hydrological context}

This study focuses on the area where the runoff responsible for the red flood is produced. This area is situated in the middle Niger basin, in the Sahelian belt, between Ansongo $\left(15^{\circ} 40^{\prime} \mathrm{N}, 0^{\circ} 30^{\prime} \mathrm{E}\right.$; Mali) and Niamey $\left(13^{\circ} 31^{\prime} \mathrm{N}, 2^{\circ} 6^{\prime} \mathrm{E}\right.$; Niger) as contoured in red in Fig. 1 (left panel). The right bank of the Ansongo-Niamey reach collects three main tributaries (Fig. 1 zoomed in image): the Gorouol (in Alcongui), the Dargol (in Kakassi) and the Sirba (in Garbey). These are the first tributaries of the Niger River since the inner delta. The Gorouol, Dargol and Sirba are ephemeral rivers, named koris, which flow only during the rainfall season. The left bank of the Niger in the study zone is mainly endorheic. The hydrographical network is organised in connected ponds and the runoff does not contribute much to the Niger River. Amogu et al. (2010) and Mamadou et al. (2015) have reported, however, that in parts of the left bank the hydrographical network is changing and water channels are created down to the main river bed; this phenomenon is known as 

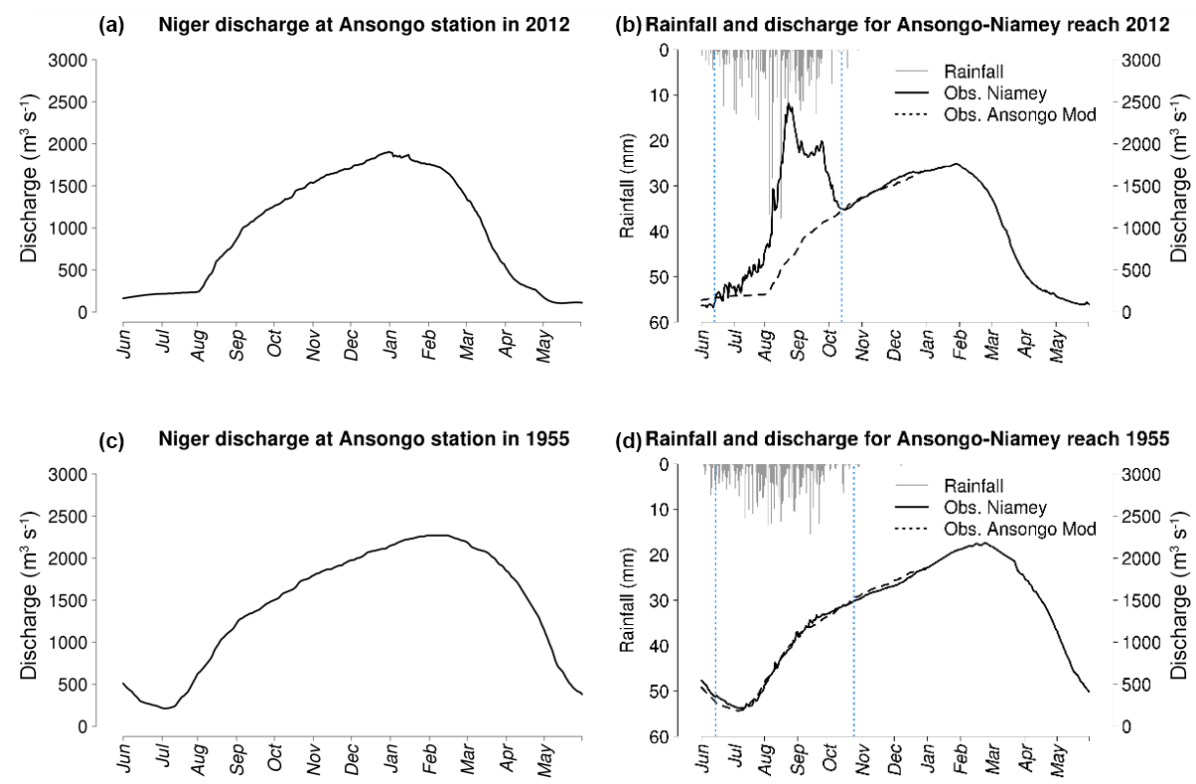

Figure 2. Discharge of the Niger in Ansongo station in 2012 (a) and 1955 (c) and discharge of the Niger in Niamey (black line) and Ansongo (dashed line) after morphing (see Sect. 2.3) in 2012 (b) and 1955 (d). The downwards grey bars in (b) and (d) are the daily rainfall in Ansongo-Niamey reach basin. The dotted blue vertical lines in (b) and (e) indicate the beginning and the end of the red flood period.

endorheic rupture and increases the runoff contribution from the left bank to the Niger main stream.

Figure 2 displays the discharge recorded at Ansongo and Niamey gauging stations in 2012 and 1955; 2012 is a good illustration of a strong red flood event in Niamey. As discussed in the introduction and visible in Fig. 2b, the discharge in Niamey is the superposition of the Guinean flood, arriving from the upper Niger basin (as seen at Ansongo, Fig. 2a) and of the additional runoff generated in the Gorouol, Dargol and Sirba basin between July and October.

\subsection{Discharge data}

Five discharge gauging stations within the studied zone are used to analyse the observed changes and also as input or validation for the model simulations. Ansongo (Mali) at the head of the study zone is needed to analyse the Guinean flood before any influence of the red flood on the discharge. Ansongo data are also needed as input to the hydrological model (see below). The discharge in Niamey is the main focus of this work, and is the best quality data record of all five stations. It is also the only station used to validate the model output. The discharge at the three right bank tributary outlets (Alcongui, Kakassi and Garbey) is used to quantify the locally generated runoff and its variability over the years. All discharge data are provided by the Niger Basin Authority (ABN) database. The data set covers 60 years from 1953 to 2012 for Ansongo and Niamey (with a significant number of missing data during low-flow water in Ansongo during 1960s and 1990s), and 1957-2012 period for Alcongui, Kakassi and Garbey stations with 28 complete common years $(1957,1963$ to $1975,1977,1979,1980,1982$ to 1987,2006 to 2008 and 2012).

\subsection{Quantifying the red flood contribution to Niamey's discharge}

As the study focuses on the red flood in Niamey, a first challenge is to isolate this flood from the Guinean flood in the Niamey discharge, based on available observations. For recent years, where the two floods are clearly independent (Fig. 2b), an automatic algorithm based on maxima detection can be implemented. For distant years where the two floods were almost merged (Fig. 2d) the task is difficult. A two-step method suitable for both merged and non-merged flood hydrographs is implemented. First, the period where the runoff leading to the red flood occurs is delimited. Second, the red flood contribution is quantified based on comparing Niamey's and Ansongo's discharge.

For each year the red flood period is delimited based on the observed rainy season, as illustrated with the vertical lines in Fig. $2 b$ and $d$. The longest rainfall record, available for the whole 1953-2012 period is used (see Sect. 2.4 below). The starting date of the red flood period is set as the day when $10 \%$ of the annual rainfall amount is reached. The end date is set to the day when $98 \%$ of the annual rainfall is reached plus a 10-day margin. The margin accounts for the time needed for runoff over the entire drainage area to reach Niamey.

Once the red flood period is delimited, the next step is to quantify the proportion of Niamey's discharge attributable to runoff in the Ansongo-Niamey sub-basin, from what is propagating from the upper basin. Two methods have been used. 
The first method assumes that the main runoff contribution between Ansongo and Niamey comes from the three right bank tributaries. With this assumption the sum of the three discharges can be used as a proxy. This method however occults the contribution of direct rainfall over the river bed or runoff from the left bank. Also the station records are not available on the entire studied period. The second method is based on subtracting the Ansongo's discharge from the Niamey's discharge. Note that during the Guinean flood (Fig. 2a and c) the discharge in Ansongo is higher than in Niamey (Fig. 2b and d). The source of this loss is not yet understood; according to $\mathrm{ABN}$ experts it may come both from evaporation and water loss through bedrock fractures or flush back from the Niger main stream into dry koris after the rainy season. This loss must be accounted for, before subtracting Ansongo's from Niamey's discharge. To do so, Ansongo's discharge is morphed to fit the shape of the Guinean flood as observed in Niamey. This is illustrated by the difference between the dash line in Fig. 2b (Fig. 2d) and the plain line in Fig. 2a (Fig. 2c). Then, the local red flood contribution is estimated as the area between Niamey's discharge (black line in Fig. 2b) and Ansongo's morphed discharge (dash line), between the beginning and end of the red flood period (vertical blue lines in Fig. 2b).

Whatever the method used, the estimation of local runoff production is prone to uncertainty. In method one (sum of three tributaries discharge) the errors may come from the quality of the data record and ignoring rainfall over the river bed and the left bank. In method two, most of the error comes from the quality of the data record in Ansongo and also from the difficulty to quantify the losses in the discharge between Ansongo and Niamey. In any case, the objective here is not an accurate quantification of the runoff every year but rather the analysis of the main trends and relative changes over 60 years.

\subsection{Rainfall data record}

Rainfall data are used in Sect. 3 to analyse the observed changes in the climatic and hydrological signals. It is also needed as forcing for the hydrological model.

Rainfall over the Niger basin is associated with the West African monsoon and occurs mainly between June and October. In the studied area, like in overall Sahel, $90 \%$ of rainfall comes from propagating mesoscale convective systems (MCSs) (Laurent et al., 1998; Mathon et al., 2002; Lebel et al., 2003). Although MCS patterns vary, they often organise in a curved convective line followed by a stratiform region (Houze, 1993). The resulting rain fields are characterised by strong space-time variability, with intense rain rates when the convective front is passing through (typically during less than an hour in a given point at ground) followed by a few hours of less intense rainfall in the stratiform part. Reproducing this highly spatially and temporally variable patterns is a challenge for the different rainfall products. This is an im- portant point with forcing models because the hydrological response depends not only on the accumulations but also on the distribution of rainfall in time, space and intensity classes (Gosset et al., 2013; Casse et al., 2015). Three rainfall data records have been used in this work (Table 1). All three are spatialised rainfall products, provided on a regular grid and well suited for forcing a distributed hydrological model. Two of the products are based on rain gauge information and one on satellite information. The three products are described below. The appendix A compares the three products and confronts them with a reference, both in terms of rainfall amount and distribution (in time, space and intensity).

\subsubsection{KRIG: a research product based on a rich set of operational gauges (available since 1950)}

This regional product provided by the Laboratoire des Transfert en Hydrologie et Environnement (LTHE), hereafter named the KRIG product, is a gauge-based rainfall estimate. This product is based on a database first built by Le Barbé et al. (2002) and updated by Panthou et al. (2014). The KRIG product is based on rain gauge records from different institutes: the Centre Inter-Etats d'Etudes Hydraulique (CIEH), the AGRometeorology, Hydrology, METerology centre (AGRYMET) and the National Weather services from several African countries (DMN in French). The available network density is variable during the period and inside the basin. Over the studied area and after quality control, the available number of stations ranges from 60 to 15 gauges between 1950 and 2012, and since 2006 the network has been sparser, with less than 30 gauges (Fig. 3). As in Vischel et al. (2011), the kriging technique is used to interpolate the daily gauge information and provide a regularly gridded product with a $0.5 \times 0.5^{\circ}$ resolution. We checked the impact of the variation of the number of gauges over the domain on the inter-annual trends in rainfall (presented in Sect. 3). We found (not shown) that the main trend is not modified when using a network of only 10 gauges (those available for the whole series).

\subsubsection{CPC: an operational gauge product (available since 1979)}

The National Oceanic and Atmospheric Administration (NOAA) Climate Prediction Centre (CPC) provides the CPC Unified Gauge-Based Analysis of Global Daily Precipitation (here after named CPC, and available on http://ftp.cpc.ncep. noaa.gov/precip/CPC_UNI_PRCP/GAUGE_GLB/) (both data and documentation). This daily $0.5^{\circ}$ product, available from 1979 to present, is based on the Gandin (1965) optimal interpolation, which according to Chen et al. (2008) provides a robust global precipitation estimate in different conditions of climate, season and network density. On the contiguous United States, a correlation of 0.5 was found between the referenced network (30 km station-to-station distance) and 
a synthetic sparse network, which mimics a tropical Africa situation (400 km station-to-station distance) (Chen et al., 2008). On the Ansongo-Niamey reach basin, the annual mean number of gauges has been increasing over the period and ranges from 1.5 (1980) to 6.2 (2010) (Fig. 3). This density is very low compared to the density provided by the KRIG product above. Casse et al. (2015) however showed that a hydrological model forced with CPC gave satisfactory results over the area for the 2000-2013 period, where the annual mean number of gauges is around 5.2 $( \pm 0.66)$.

\subsubsection{PERSIANN-CDR: a satellite-based product (available since 1983)}

Based on the PERSIANN algorithm (Sorooshian et al., 2000), a new climate data record called PERSIANN-CDR (Ashouri et al., 2015) with a daily $0.25^{\circ}$ resolution is currently available from 1983 to present (https://www. ncdc.noaa.gov/cdr/atmospheric/precipitation-persiann-cdr). PERSIANN-CDR is based on high temporal resolution infrared information from geostationary satellite (GridSatB1, from the International Satellite Cloud Climatological Project, ISCCP) and it is bias corrected with the Global Precipitation Climatology Project (GPCP, Huffman et al., 1997, 2009) monthly rainfall estimates (Ashouri et al., 2015).

\subsection{Hydrological model and set-up}

The hydrological simulation is based on the ISBA (Interaction between Soil Biosphere and Atmosphere)-TRIP (Total Runoff Integrating Pathway) model, already used in Casse et al. (2015) and Casse and Gosset (2015) to study the Ansongo-Niamey reach of the Niger basin. Casse et al. (2015) tested the model over the 2000-2013 period with a variety of rainfall products. They showed that ISBA-TRIP was able to reproduce the frequency of red floods in the recent period. Casse and Gosset (2015) used the same model and the rainfall product PERSIANN-CDR to study the 19832012 period, also with satisfactory results.

\subsubsection{The ISBA-TRIP coupled model}

Within the SURFEX modelling platform (developed by Météo France and standing for SURFace Externalisée in French; http://www.cnrm.meteo.fr/surfex/, Masson et al., 2013), a land surface model (LSM) is coupled to a routing model.

The LSM, called ISBA, computes the water (and energy) balance based on the soil/vegetation properties of each grid cell and the atmospheric forcing provided at each time step. Several options are available within ISBA to produce runoff; here the production is based on a parameterisation of subgrid hydrology. This allows one to take into account the high spatial variability of rainfall and runoff processes within a $0.5^{\circ}$ cell (Decharme and Douville, 2005, 2007).
ISBA output feeds the routing model called TRIP, which turns surface runoff, groundwater and floodplain water contributions into discharge for each grid cell, and then propagates the surface flows through the river network. TRIP reservoirs implemented in the version 6 of SURFEX (used in this study) are the river, the groundwater, the flood plain and the aquifer. Within these reservoirs, evaporation and infiltration occurs only in flood plains. Distributed parameters (based on physical equation or on fixed values) control the river hydrology: length, slope, width, depth, Manning coefficients of river and flood plain, partitioning coefficient between groundwater and aquifer, return time of groundwater and aquifer to the river.

For more details on the ISBA-TRIP model physics, please refer to Noilhan and Planton (1989; first developers), Boone et al. (1999; for the soil layers physics), Decharme et Douville (2005 and 2007; for the subgrid hydrology), Decharme et al. (2006; for vegetation impact on infiltration) or Pedinotti et al. (2012, for the implementation on the Niger basin).

The model is implemented on the Ansongo-Niamey reach basin (Fig. 4) with a grid resolution of $0.5^{\circ} \times 0.5^{\circ}$ and a $3 \mathrm{~h}$ time step for the atmospheric forcing. This configuration is described in detail in Casse et al. (2015) and Casse and Gosset (2015). The value of the daily discharge at the head of the reach (Ansongo pixel) is needed as input. The observed discharge data at the Ansongo station provided by the ABN are used for this purpose.

\subsubsection{Atmospheric forcing}

ISBA needs a classical atmospheric forcing (precipitation, temperature, pressure, humidity, radiance and wind) to compute the water balance for each grid cell. Here the atmospheric forcing, except for rainfall, is provided as a climatological mean value for each day. The daily mean value was computed from the 2003-2012 period based on the WATCH (Water and Global Change) Forcing Data methodology applied to ERA-Interim data (WFDEI; Weedon et al., 2011, 2014), re-analysed by Météo France (B. Decharme, personal communication, 2013). Sensitivity tests (not shown) have been run to verify the sensitivity of the model output to this atmospheric forcing. The tests showed that using a climatological mean does not impact the simulated discharge and does not change the characteristic of the simulated red flood.

The rain forcing is provided by the three rainfall data sets described in Sect. 2.4, PERSIANN-CDR, CPC and KRIG. Their native resolution (daily and 0.5 or $0.25^{\circ}$, Table 1) differs from the resolution of model forcing input $\left(3 \mathrm{~h}-0.5^{\circ}\right)$. Daily rainfall is thus disaggregated at a $3 \mathrm{~h}$ time step following a very simple process. Observation over the studied region, based on dense gauge networks (http://www.amma-catch.org/) and meteorological radar (http://meghatropiques.ipsl.polytechnique.fr/ the-ouagadougou-super-site.html) shows that daily rainfall is concentrated in a few hours. This observation is in ac- 
Table 1. Summary of the different rainfall estimate products characteristics.

\begin{tabular}{|c|c|c|c|c|c|c|c|c|c|}
\hline & Data & Cover & $\begin{array}{l}\text { Temp. } \\
\text { res. }\end{array}$ & $\begin{array}{l}\text { Spa. } \\
\text { res. }\end{array}$ & Dates & Used period & Agencies & Ref & Web \\
\hline KRIG & in situ & & Daily & $0.5^{\circ}$ & $1950-2012$ & 1953-2012 & LTHE & $\begin{array}{l}\text { Panthou et } \\
\text { al. (2014) }\end{array}$ & \\
\hline CPC & in situ & Global & Daily & $0.5^{\circ}$ & 1979-present & 1983-2012 & NOAA/CPC & $\begin{array}{l}\text { Chen et al. } \\
\text { (2008) }\end{array}$ & $\begin{array}{l}\text { http://www. } \\
\text { cpc.ncep.noaa. } \\
\text { gov/products/ } \\
\text { international/ } \\
\text { index.shtml }\end{array}$ \\
\hline PERSIANN-CDR & satellite in situ & $60^{\circ} \mathrm{N}-\mathrm{S}$ & Daily & $0.25^{\circ}$ & $1983-2013$ & 1983-2012 & NOAA & $\begin{array}{l}\text { Ashouri et } \\
\text { al. (2015) }\end{array}$ & $\begin{array}{l}\text { http: } \\
\text { //www.ncdc. } \\
\text { noaa.gov/cdr/ } \\
\text { operationalcdrs. } \\
\text { html }\end{array}$ \\
\hline
\end{tabular}

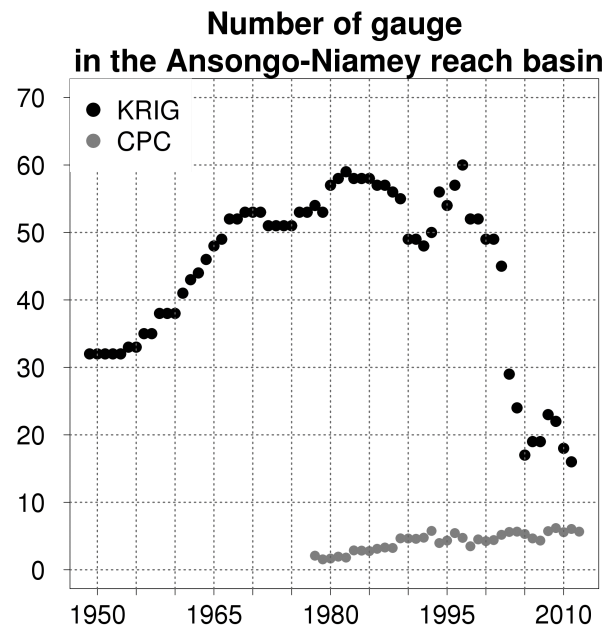

Figure 3. Number of rain gauges for the two in situ rainfall estimates products KRIG (black dots) and CPC (grey dots) on the Ansongo-Niamey reach basin.

cordance with previous studies on MCS dynamics (Eldridge, 1957; Rowell and Milford, 1993). For the model forcing the daily rainfall accumulation is condensed in one $3 \mathrm{~h}$ time step (between 16:00 and 19:00), as in Casse and Gosset (2015). The $0.25^{\circ}$ resolution product (PERSIANN-CDR) is spatially aggregated by spatial mean.

Since the model is not calibrated for each product, the differences between the three simulations are due to differences between the rain products (Appendix A1). Three independent rainfall data sets consolidate the conclusions concerning the role of rainfall changes on hydrology.

\subsubsection{Vegetation map}

ISBA computes energy and water balance based on empirical equations and vegetation and soil properties. In the reference simulation the vegetation map (vegetation type and (a) ISBA-TRIP with recent conditions
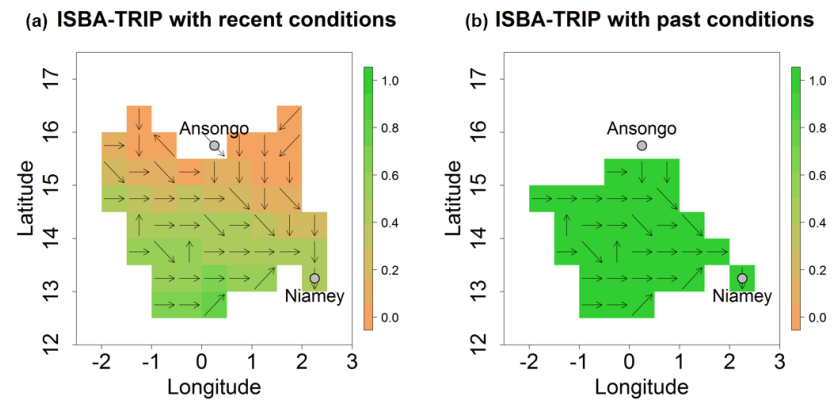

Figure 4. ISBA-TRIP domain implemented on the AnsongoNiamey reach basin. The colour scale represent the vegetation fraction on the area. Green colour and values close to 1 indicate full vegetated cells and brown colour and values close to 0 indicate bare soil.

fraction, Fig. 4a) is based on the Ecoclimap data (Masson et al., 2003; which covers the 2002-2006 period) and the soil texture (sand, silt proportion) is based on FAO data. These data sets are considered representative of the current conditions in the area. The bare soil proportion on the basin ranges from 20 to $100 \%$ and follows the rainfall latitudinal gradient with less vegetation in the north than in the south. Within ISBA, the vegetation cover of the Ansongo-Niamey reach basin is composed mainly of Sahelian savannah and bush Sahelian savannah, which present low coverage $(\mathrm{LAI}<2$ and at least $20 \%$ of bare soil). Contrary to landscape description found in the literature (Amogu et al., 2010; Descroix et al., 2012), Ecoclimap data do not consider any croplands in the study area. However, sensitivity studies (not shown) have highlighted that the model is sensitive to the vegetation cover fraction (leaf area index - LAI and proportion of bare soil) rather than to the vegetation type (crop vs. no crop). Thus, LULC changes impact on hydrology is explored by changing the vegetation cover fraction.

The simulations over the whole 1953-2012 period are first run with the current soil/vegetation characteristics (Fig. 4a), 
with the objective to analyse only the impact of rainfall regime changes. In a second step the vegetation cover fraction is changed to be more representative of the beginning of the period, with less area covered by bare soil and more wood (Fig. 4b).

\section{Observed rainfall and hydrological changes since 1950s}

This section summarises the hydrological and climatic changes observed over the study area since the 1950s. The analysis is based on the inter-annual series of the normalised rainfall index and similar indices computed for the discharge. The normalised rainfall index, for a series of $\mathrm{N}$ annual rainfall accumulation values $R_{i}$ (here $N=60$ ) is defined each year $i$ by

$I_{i}=\frac{R_{i}-\bar{R}}{\sigma_{R}}$,

where $\bar{R}$ and $\sigma_{R}$ are the mean and the standard deviation of the $R_{i}$ series. The rainfall index is based on the KRIG rainfall estimates (the only product available over the entire period).

The variability of the discharge in Niamey is analysed in light of the variability of its two components: (i) the Guinean flow arriving through Ansongo and (ii) the runoff generated over the Ansongo-Niamey sub-basin. These indices have been computed from the following red flood discharge time series:

- the annual mean discharge in Ansongo (in $\mathrm{m}^{3} \mathrm{~s}^{-1}$ );

- the annual mean discharge in Niamey (in $\mathrm{m}^{3} \mathrm{~s}^{-1}$ );

- the annual mean differential discharge, computed as the difference between the Niamey and the morphed Ansongo discharges;

- the annual mean of the sum of the discharges from the three tributaries (Dargol, Sirba and Gorouol).

As discussed in Sect. 2.3, the two last variables are proxies to the local runoff contribution to Niger discharge.

Figure 5 illustrates the rainfall and hydrological changes in the Ansongo-Niamey reach basin through 6 decades, from 1953 to 2012.

Figure 5a shows that the 1950s and 1960s are the wettest decades of the studied period (all years present a positive rainfall index), followed by 2 decades with rainfall deficit in the 1970s and 1980s (starting in 1968). Since the 1990s the rainfall index has presented strong inter-annual variability; it is higher than in the dry period but still below the wettest decades. These results, derived for the AnsongoNiamey reach basin with the KRIG rainfall data set, are consistent with the three main climatic periods the Sahelian region has undergone since 1950 (Lamb, 1982; Le Barbé and
Lebel, 1997; Nicholson et al., 2000; Camberlin et al., 2002; Le Barbé et al., 2002; L'Hôte et al.; 2002, Dai et al., 2004; Lebel and Ali, 2009; Panthou et al., 2014). Both wet and dry decades were observed and the heterogenous rainfall recovery highlighted by several authors (Nicholson et al., 2000; L'Hôte et al., 2002; Dia et al., 2004; Lebel and Ali, 2009; Panthou et al., 2014) is confirmed over the studied area.

Figure 5b, c and d illustrate the inter-annual variability of respectively, the mean discharge in Niamey during the red flood period (Fig. 5d), and its two contributors: the Guinean flow as recorded in Ansongo (Fig. 5b) and the local runoff (Fig. 5c). In Fig. 5c the two proxies used to quantify local runoff contribution to the discharge (Sect. 2.3) are displayed. The grey shade is for the index computed from the differential discharge between Ansongo and Niamey; the yellow colour is for the index based on the sums of the tributaries. The gaps in the latter series are due to missing data.

As expected, the trends in the Ansongo discharge variability are consistent with what is known of rainfall variability in West Africa and Sahel over the last 60 years: the wet decades of the 1950s and 1960s are associated with the highest discharge index, the long period with negative index during the 1970s and 1980s highlights the decrease in discharge during the drought in the upper Niger basin. From the 1990s the discharge index has increased again but in still lower than in the 1950s-1960s wet conditions and shows an enhanced interannual variability.

In contrast with the relatively similar trends displayed by rainfall (Fig. 5a) and the Ansongo discharge (Fig. 5b), the index for the local runoff contribution (Fig. 5c) shows a very different evolution over the 6 decades. The salient feature is an increase over the period with mostly negative values until the mid-1980s and increasing positive values afterwards. Given the many sources of uncertainty in deriving the two proxies (Sect. 2.3) the agreement is quite remarkable and shows that the observed trend is robust. Both proxies agree that wet decades present a smaller index than drier ones, indicating that runoff in the Ansongo-Niamey basin tends to increase over the entire studied period, with a sharp increase since the 1990s. This result reflects the paradoxical behaviour of Sahelian basins described by several authors (Albergel, 1987; Amani and Nguetora, 2002; Mahé et al., 2003, 2005; Mahé et Paturel, 2009; Descroix et al., 2009, 2012; Sighomnou et al., 2013). Previous studies have attributed the changes in the runoff coefficient to the effect of LULC changes (Seguis et al., 2004; Leblanc et al., 2008; Descroix et al., 2009, 2012). The reason for the sharp increase in runoff since the 1990s and the possible role of rainfall intensification is debated in the community. Analysis at the yearly scale as presented above does not allow one to conclude. The model-based simulations in the next section shed some light on these questions.

As expected, Niamey red flood (Fig. 5d) changes over 1953-2012 reflect the influence of the flow coming from the upper basin (Fig. 5b) and local contributions (Fig. 5c). In the 

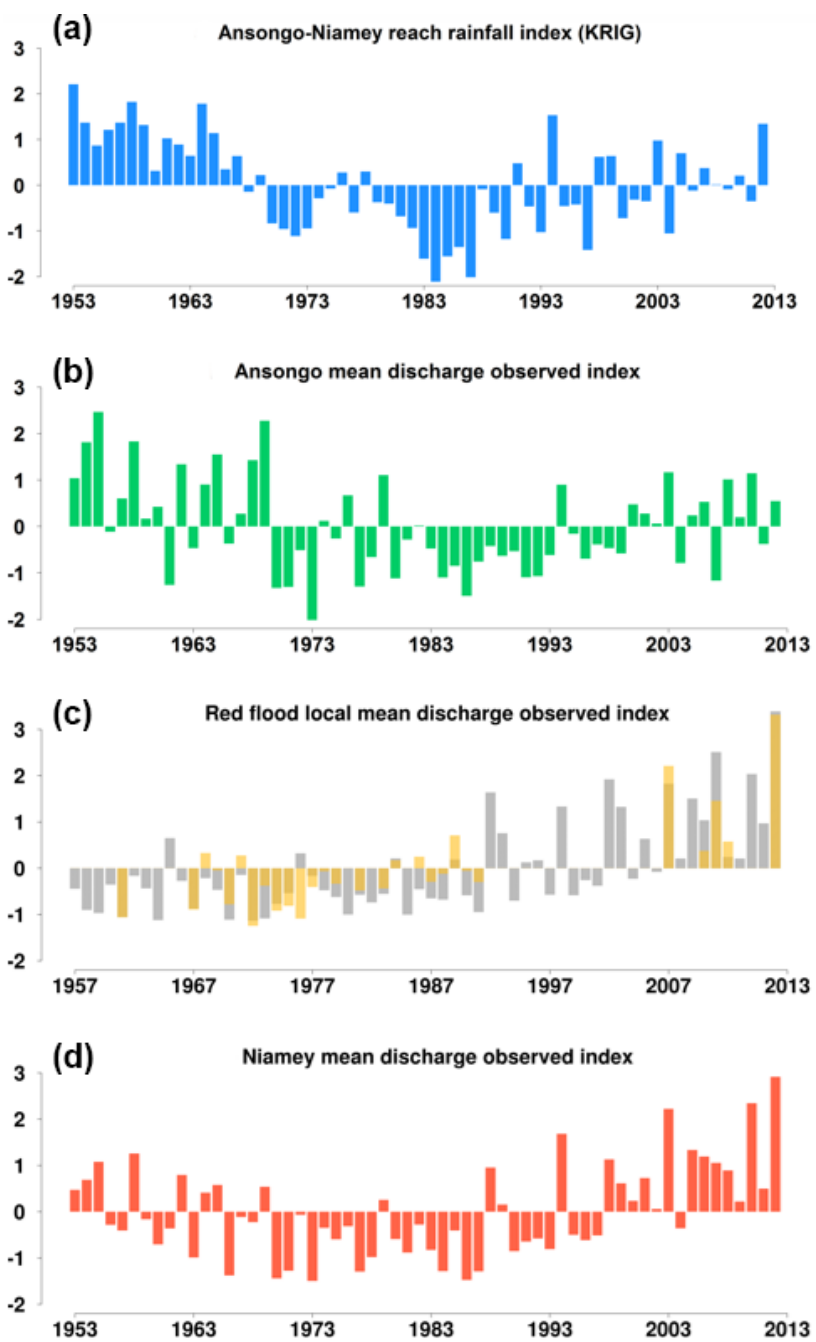

Figure 5. Evolution between 1953 and 2012 of the normalised indices of rainfall (a), red flood period mean discharge in Ansongo (modified after morphing method, see Sect. 2.3) (b), red flood period mean differential discharge between Ansongo and Niamey (c, grey), red flood period mean discharge of the three right bank tributaries (c, yellow) and red flood mean discharge Niamey (d).

1950s and 1960s when the upper flow is high but local runoff is small, the mean discharge index is average, with a succession of positive and negative years. During the 1970s and 1980s drought it reaches the lowest values. In the recent period when the index for the upper basin flow is average but local runoff is increasing sharply, the red flood levels increase drastically and reach their highest values.

\section{Model-based analysis, sensitivity tests and attribution of the changes}

This section presents the modelling results and their ability to reproduce the hydrological changes discussed in the previous section. First, for the entire simulated period (1953-
2012) the soil/vegetation parameters and drainage area are held constant and are in agreement with the present conditions (Fig. 4a). The only source of variability is the discharge in Ansongo and the rainfall forcing. If this simulation is able to reproduce the hydrological observed changes, then rainfall variability can be considered as the main driver for the hydrological changes. If not, other possible drivers such as LULC and drainage area should be explored. The results are first presented for 1983-2012 when three different rainfall forcing are available. The simulations since 1953, with KRIG rainfall only, are then presented.

\subsection{3-2012 period}

\subsubsection{Mean decadal hydrograph}

The mean decadal hydrograph is a good synthetic indicator of the salient changes in the hydrological regime between the decades. The observed and simulated decadal hydrograph for the last 3 decades (1983-1992, 1993-2002 and 2003-2012) are presented in Fig. 6. According to Fig. 6a the observed discharge has globally increased through the 3 decades, both in terms of flood length and intensity. The increase in the Guinean flood (November to May) is consistent with the increase in the Ansongo discharge already discussed (Fig. 5b). The progressive apparition of the red flood, clearly separating from the Guinean flood in the last decade (2003-2012), is visible in Fig. 6a. The decadal mean of the total water volume during the red flood (integration of Niamey discharge during the red flood) increased from 5.1 to $8.9 \mathrm{~km}^{3}$ during the 3 observed decades (Table 2). The enhancement of the red flood due to the combined effect of an increase in the upper basin flow (Fig. 5b) and local runoff (Fig. 5c) is visible on the decadal hydrographs.

The simulated decadal mean hydrographs, based on the three rainfall forcing - KRIG, CPC and PERSIANN-CDR - are able to reproduce the main features of the observed changes: the red flood increase and the progressive bi-modal shape reinforcement (Fig. 6b, c, d and Table 2). Results show also discrepancies among the three simulations: KRIG rainfall leads to a smoother simulated red flood than CPC and PERSIANN-CDR, which tend to overestimate the observed discharge. As developed in Appendix A, the three rainfall data sets estimate well the annual rainfall amount but distribute it differently in time, space and intensity. As already highlighted in Casse et al. (2015), this difference in rainfall distribution impacts the hydrological response.

During the Guinean flood, all simulations overestimate the discharge. This systematic overestimation is mainly due to the observed deficit between Ansongo and Niamey (Sect. 2.2), which is not simulated by the current modelling. 


\subsubsection{Quantile-quantile analysis}

The frequency distribution of the daily discharge during the red flood for each decade is analysed. The simulated and observed distributions are compared in two ways: (i) first the observations and simulations are compared decade by decade (Fig. 7), in order to verify the ability of the model to reproduce realistic distributions of the daily discharge; (ii) then the relative changes in the distributions, between decades, are analysed both for observations (Fig. 8a) and for simulations (Fig. 8b, c and d).

The distribution comparison between simulated and observed daily red flood discharge (Fig. 7) for the 3 decades highlights that the simulations tend to overestimate the observed discharge. This is true for CPC and PERSIANN-CDR for the whole distribution, and for KRIG for low and medium values. This is confirmed in Table 2 with the values of the mean decadal volume of the red flood. The observed deficit between Ansongo and Niamey, which is not simulated, may explain these overestimations. The differences among the three simulations are due to differences in rainfall distribution among the three rain products (Appendix A). The KRIG-based simulation tends to underestimate the highest discharge values. This is due to the tendency of this product to smooth rainfall fields in time (high number of rainy days with low intensities). The CPC-based simulation overestimates steadily the discharge because this products provide high intensity and the rainfall fields are concentrated in time and space. PERSIANN-CDR's behaviour lies between these two products.

Despite the overall positive bias, the simulations reproduce the observed relative changes between the driest (19831992) and the most recent decade (2003-2012) (Fig. 8): an overall increase of the discharge. For the 1993-2002 decade, simulations are too close to the 2003-2012 distribution while in the observations the 1993-2012 distribution is closer to the driest decade 1983-1993. Ansongo input discharge quality is lower during the 1990s, which may lead to more uncertainties in the 1993-2002 simulations.

These results show that with constant LULC and drainage area conditions, the simulations are able to reproduce the main trends of the hydrological regime changes between 1983 and 2012: the discharge increase and the red flood reinforcement are well simulated. Inter-annual rainfall variability can thus be considered as the main driver for the hydrological changes during 1983-2012 period, as already found in Casse and Gosset (2015). Here, the use of three different rainfall products, based on different data sets, with different characteristics over the domain (Appendix A), reinforces the results.

\section{$4.2 \quad 1953-2012$ period}

Over the 1953-2012 period, the observed mean decadal hydrograph (Fig. 9a) varies according to the three climatic peri- (a) Niamey observed discharge
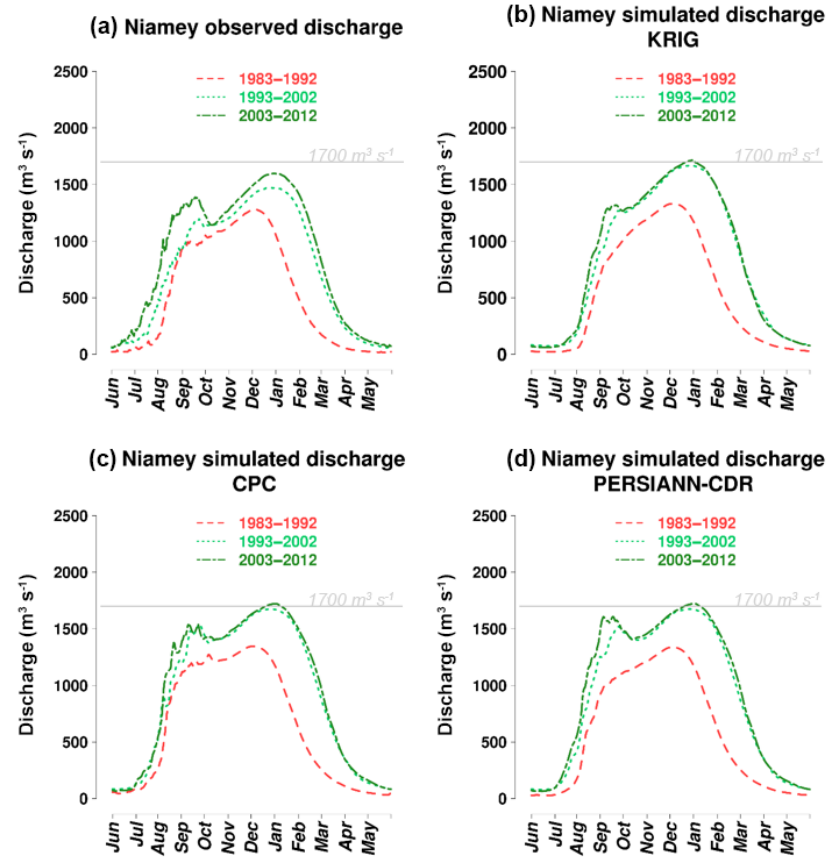

Figure 6. Observed and simulated decadal mean Niamey discharge between 1983 and 2012.

ods observed in Fig. 5a: (i) the highest discharge and longest high water level season are observed during the wettest decades (1953-1962 and 1963-1972), (ii) discharge decreases during the first dry decade (1973-1982) and reaches its lower level during the driest decade (1983-1992), (iii) before rising up over the 2 last decades (1993-2002 and 20032012), but without reaching the 1950s-1960s levels. From 1953 to 1982 , the decadal hydrograph is unimodal. A few individual years present a bi-modal shape, but these are too few to influence the decadal mean. In any case the red flood level never exceeds the Guinean flood in these early decades. In the last decade (2003-2012) the bi-modal hydrograph shape reflects the increase in intensity and frequency of the annual bi-modal regime and the occurrence of the red flood overpassing the Guinean flood (2012, Fig. 2b). Based on the total water volume of the red flood two major periods appear, consistent with the annual mean Niamey red flood discharge index (Fig. 5d): (i) 1953 to 1993 characterised by a decrease of the decadal mean volume during the rainy season (from $7.3 \mathrm{~km}^{3}$ in $1953-1962$ to $5.1 \mathrm{~km}^{3}$ in $1983-1992$ ) and (ii) 1993 to 2012 characterised by a steady increase towards the highest values of the whole period (from $7 \mathrm{~km}^{3}$ in 1993-2002 decade to $8.9 \mathrm{~km}^{3}$ in 2003-2012). As previously highlighted in Fig. 5d, the recent red flood (since the 1990s) is higher than during the wettest decades.

The simulation reproduces well the unimodal shape of the 1973-1982 hydrograph (Fig. 9). The daily discharge distributions are close to the observation (Fig. 10) for this decade, even though relatively to the other decades (Fig. 11) 1973- 
Table 2. Observed and simulated decadal mean total red flood volume (in $\mathrm{km}^{3}$ ), and difference between observed and simulated values (expressed in observation percentage).

\begin{tabular}{lrrrrrr}
\hline & $1953-1962$ & $1963-1972$ & $1973-1982$ & $1983-1992$ & $1993-2002$ & $2003-2012$ \\
\hline Observation & 7.3 & 6.1 & 5.6 & 5.1 & 7 & 8.9 \\
\hline \multirow{2}{*}{ KRIG } & 12.5 & 9.2 & 6.9 & 5.3 & 7.9 & 8.7 \\
& $70 \%$ & $50.5 \%$ & $23.5 \%$ & $4 \%$ & $13 \%$ & $-2 \%$ \\
\hline CPC & - & - & - & 6.6 & 8.8 & 9.3 \\
& - & - & - & $30 \%$ & $26.5 \%$ & $5 \%$ \\
\hline \multirow{2}{*}{ PERSIANN-CDR } & - & - & - & 5.4 & 8.5 & 9.6 \\
& - & - & - & $6 \%$ & $22 \%$ & $7 \%$ \\
\hline
\end{tabular}

1982 is too high compared to the observations. In Fig. 11a for observations, the 1983-1992 discharge exceeds 19731982 discharge, while it is the opposite for the simulations (Fig. 11b).

The most striking feature in Figs. 9, 10 and 11 is the overestimation of the discharge for the wettest and earliest decades 1953-1962 and 1963-1972, where the simulations produce too much runoff. For these wet decades, the discharge overestimation leads to an increase of the red flood and a reinforcement of the bi-modal shape of the decadal hydrograph (Fig. 9b), contrary to observations. The high rain rates over the area during the wet decades lead to enhanced runoff and high discharge during the red flood, whereas in the observations the red flood values are low during these decades. The red flood decadal mean volume values confirm the strong overestimation for the early decades (Table 2).

The present surface conditions (low vegetation cover and high proportion of bare soil) and drainage area lead to high runoff and local contribution. With these conditions simulations agree with the observed trends in red flood occurrence and intensity between the 1970s-1980s decades and the present period. The rainfall seems to be the main driver of the hydrological changes from the 1970 s to the 2010s. For earlier decades (1950s and 1960s) the red flood is highly overestimated, variation in rainfall alone could not explain the changes between wet period and more recent years. Changes in other drivers need to be investigated to understand the hydrological regime evolution.

\subsection{Sensitivity to LULC and drainage area changes}

Several authors have reported that the LULC and the drainage network have changed in the study area since the 20th century (Leblanc et al., 2008; Amogu et al., 2010; Mamadou et al., 2015). In this section we investigate the sensitivity of the simulated red flood discharge to the vegetation cover and to the drainage area, to assess their potential role in the observed hydrological changes in Niamey. Precise maps of the vegetation and drainage network evolution between 1953 and 2012 are not available. Therefore this part of the study investigates the impact of these changes based on a simplified representation of what has been reported by previous studies (Leblanc et al., 2008; Amogu et al., 2010; Mamadou et al., 2015). This is illustrated in Fig. 4. Figure 4b mimics the 1950s-1960s basin condition: with more vegetation cover (Sahelian wooded savanna) and a smaller drainage area (without north Gorouol and left bank) than in present days (Fig. 4a).

Three model configurations are used in this section: (i) standard set-up with present condition (SC), (ii) maximum vegetalised condition with a reduce drainage area (VCRD) (iii) and an intermediate situation with maximum vegetalised condition and entire drainage area (VC).

The discharges simulated for the decades 1953-1962 and 1963-1972, with the three configurations above are analysed in Figs. 12 and 13. The mean decadal hydrograph for the 1953-1962 decade (Fig. 12) displays a marked peak during the red flood, whatever the configuration. However the peak is lower, and closer to the observations (Fig. 9a) for the simulations based on a more vegetated basin, and even lower when the drainage area is reduced. The same effect is observed for the 1963-1972 period.

The same behaviour is found for the overall 19531962 and 1963-1972 decades, as displayed in the quantilequantile plots in Fig. 13. Changing the LULC and drainage area improves the daily distribution of the discharge and its relative position compared to the 1983-2012 period. However, unlike for observations (Fig. 11a) the red floods simulated in the 1950s-1960s are still exceeding the red floods of recent decades (Fig. 13c).

Some of the remaining positive bias in the VCRD simulation is due to the limits of the ISBA-TRIP model, which is not able to reproduce the loss between Ansongo and Niamey. The coarse resolution of the model and its simple representation of the vegetation cover and the drainage systems are also limitations. Crops or specific Sahelian ecosystems (as in tiger bush; Seghieri et al., 1994; Galle et al., 1999) are not represented explicitly in the present configuration. The complex hydrological behaviour of the temporary tributaries (koris) and their evolution within the season, when heavy rain- 
(a) QQplot observed and KRIG simulated Niamey discharge

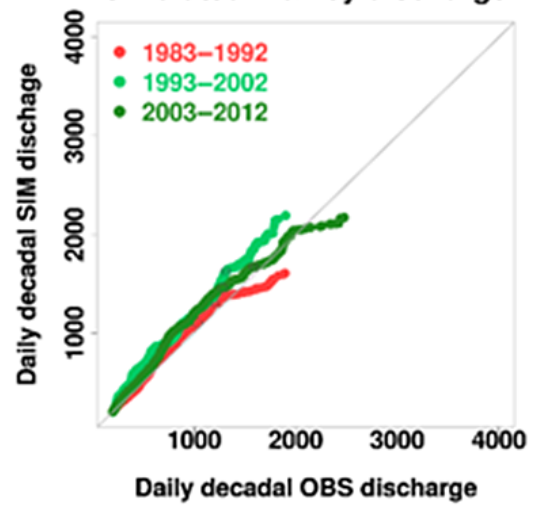

(b) QQplot observed and CPC simulatedNiamey discharge

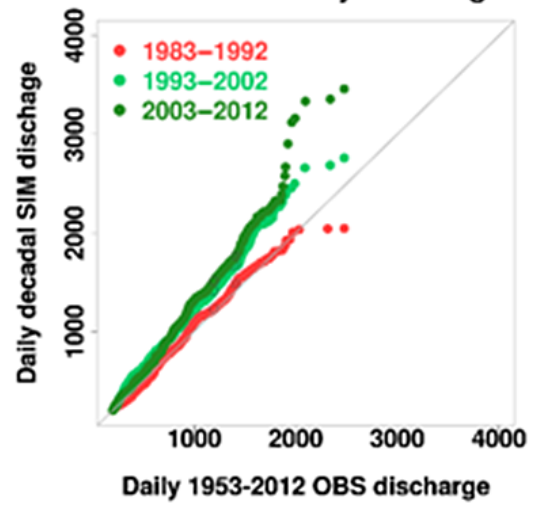

(c) QQplot observed and PERSIANN-CDR simulated Niamey discharge

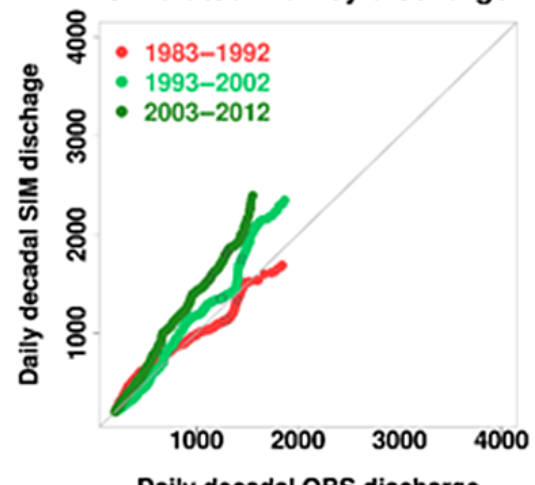

Daily decadal OBS discharge

Figure 7. Quantile-quantile plot (Q-Qplot) of the red flood period distribution of daily discharge of each decade between 1983 and 2012. The $x$ axis is for observations and the $y$ axis for the simulations.

fall may create new water pathways is not reproduced with a global model such as ISBA-TRIP.

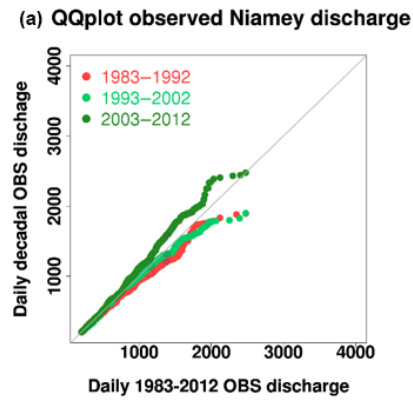

(b) QQplot discharge Niamey KRIG
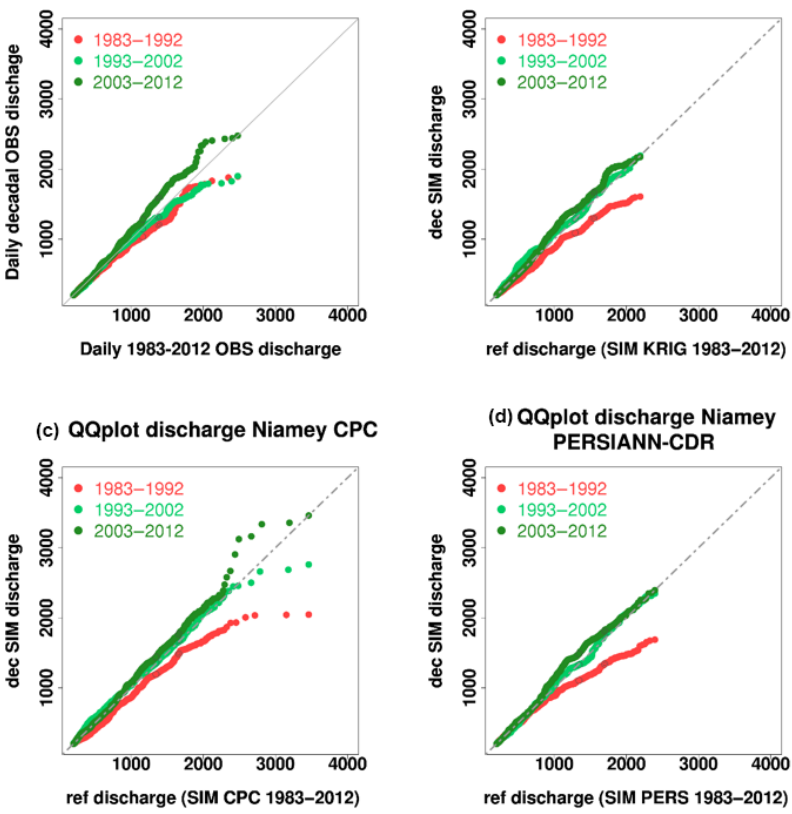

Figure 8. Quantile-quantile plot (Q-Qplot) of the distribution of daily discharge in Niamey (observed in $\mathbf{a}$; simulated in $\mathbf{b}$, c, d) for each decade, the reference ( $x$ axis) is the red flood observed/simulated daily discharge between 1983 and 2012 .
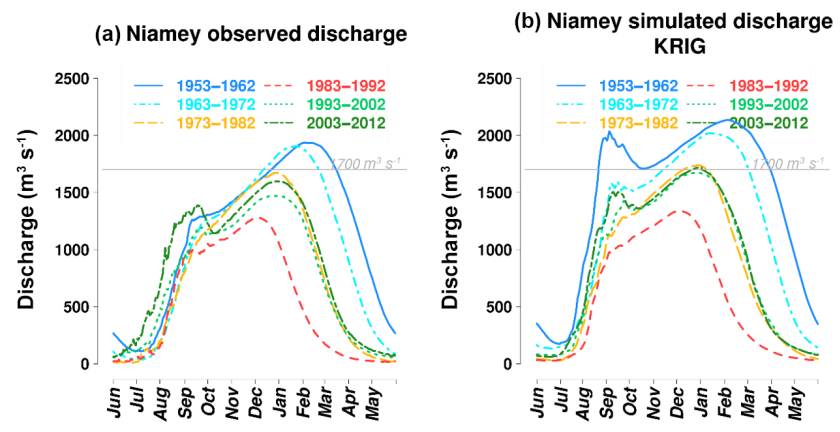

Figure 9. Observed and simulated decadal mean discharge at $\mathrm{Ni}$ amey station between 1953 and 2012 .

\section{Conclusions}

This paper analyses hydrological changes in the Sahel region since the 1950s with a focus on the middle Niger River in the vicinity of Niamey where floods have increased drastically. The study focuses on the Ansongo-Niamey reach basin where the red flood, which has caused much damage in the last decade, is generated. The rainfall over the studied area has followed the general trend that Sahel has overcome between 1953 and 2012: a wet period during 1950s and 1960s, a long drought during 1970s and 1980s and a recent partial recovery of annual rainfall. The intensity of the red flood in Niamey is influenced by the upper Niger flow arriving in 


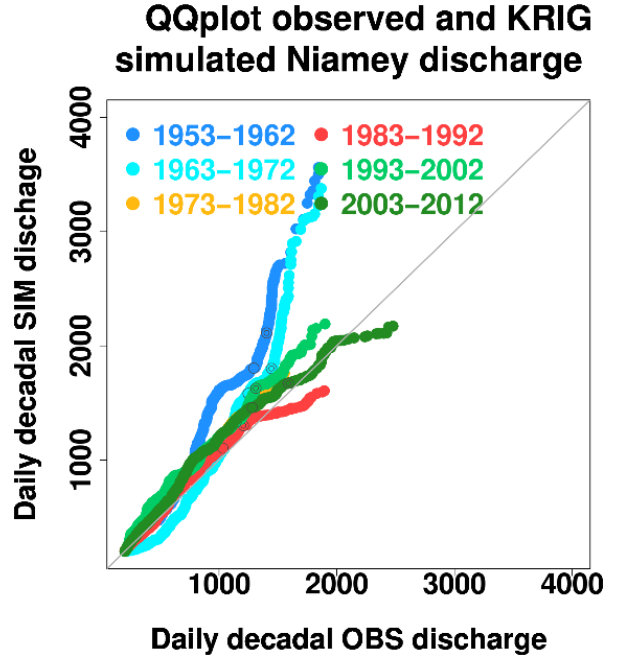

Figure 10. Quantile-quantile plot (Q-Qplot) of the red flood period distribution of daily discharge of each decade between 1953 and 2012. The $x$ axis is for observations and the $y$ axis for the simulations.
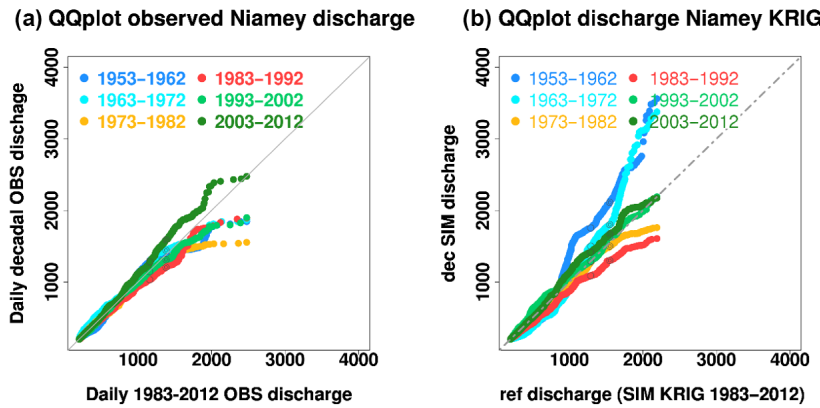

Figure 11. Quantile-quantile plot (Q-Qplot) of the distribution of daily discharge in Niamey (observed in $\mathbf{a}$; simulated in $\mathbf{b}$ ) for each decade since 1953; the reference ( $x$ axis) is the red flood observed/simulated daily discharge between 1983 and 2012 .

Ansongo and by local runoff produced in the sub-basin between Ansongo and Niamey. Changes in the red flood signal over the last 60 years are explained by the changes in both components, which have been analysed based on standard indices. The upper Niger contribution has followed the climatic trend. The corresponding index is positive during the 1950s1960s, negative during the droughts of the 1970s-1980s and varies around 0 since the 1990s. The local runoff contribution has been continuously increasing over the 1953-2012 period, which is paradoxical given the rainfall signal. This double influence results in a progressive increase of the red flood since the 1980s, and paradoxically the red flood has been higher in the last decade than in the wettest decades of the series.

This study provides a better understanding of the roles of rainfall and surface conditions (LULC and drainage area) in these observed changes, thanks to hydrological simulations. The simulations based on the current surface condi-

\section{(a) Niamey simulated discharge}

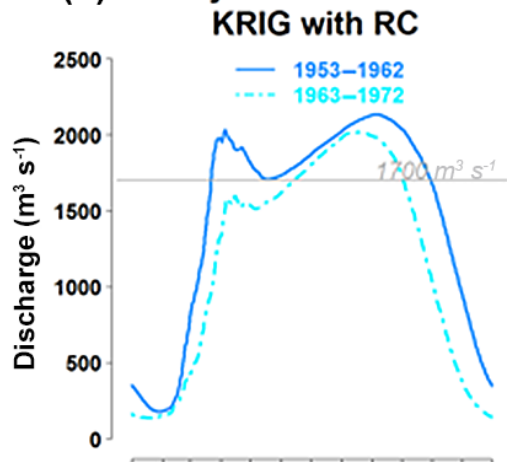

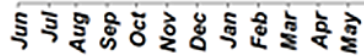

\section{(b) Niamey simulated discharge KRIG with VC}
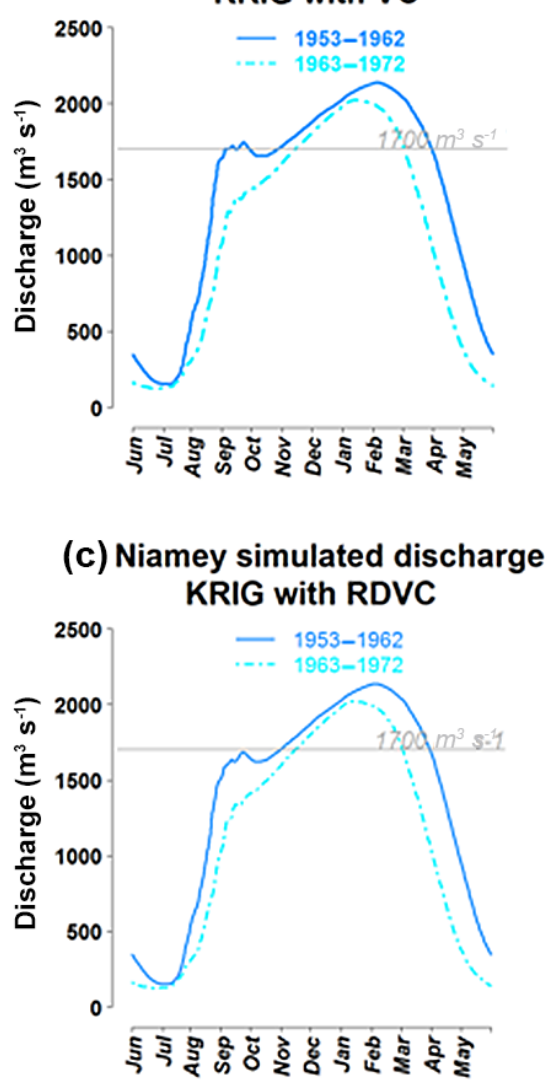

Figure 12. Simulated decadal mean discharge in Niamey with three scenarios : (a) recent surface condition (RC), (b) fully vegetated basin condition (VC) and (c) fully vegetated basin with smaller drainage area condition (VCRD).

tions are able to reproduce the observed trend in red flood occurrence and intensity since the 1980s. This has been verified with three independent rainfall data sets, which provide similar annual rainfall accumulations over the domain but with marked differences at smaller scales. This result implies that rainfall inter-annual variability is the main driver 
(a) QQplot discharge Niamey KRIG

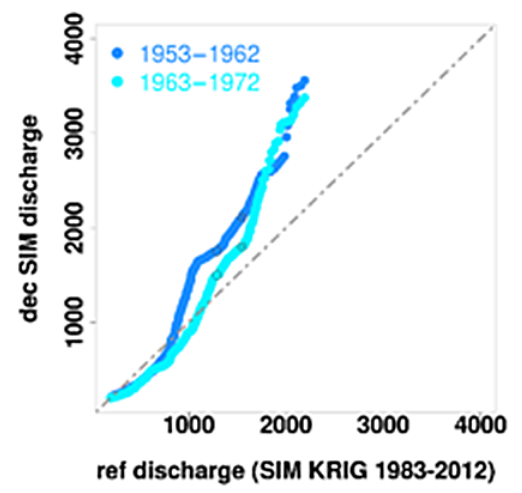

(b) QQplot discharge Niamey KRIG vegetalised area

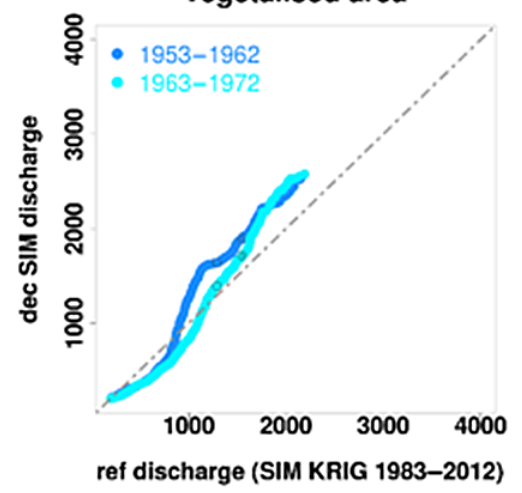

(c) QQplot discharge Niamey KRIG vegetalised and small area

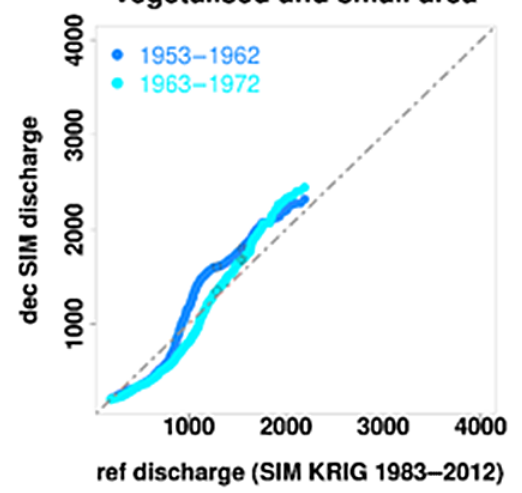

Figure 13. Quantile-quantile plot (Q-Qplot) of daily annual discharge of each decade, the reference is daily discharge between 1983 and 2012.

for the changes observed since the early 1980s: the hydrograph has become bi-modal and the red flood is intensifying. The simulation results since 1953 (only one rainfall product available) have revealed that LULC and drainage area changes should be considered. Increasing the vegetation cover and reducing the drainage area decreases the runoff production in the model and simulates discharges closer to the observations in the 1950s and 1960s. This result implies that changes in the environmental conditions are responsible for the change in hydrological behaviour between the 1950s1960 s decades and the 1970s to present period. The scenario that emerges from these results is the following: in 1950s and 1960s surface conditions, with more woody area and bare soil than in the present days, limited the runoff and thus the local contribution to the red flood despite the high rainfall amounts. Changes in surface conditions (because of climatic variations and anthropic pressure) during 1970s and 1980s have increased the runoff coefficient as already suggested by many authors (Amani and Nguetora, 2002; Mahé et al., 2003; Amogu et al., 2010; Descroix et al., 2013; Aich et al., 2015). This led to an increased local contribution to the red flood in spite of the rainfall deficit. These new surface conditions resulted in an enhanced sensitivity of the hydrological response to rainfall variability, because runoff has increased and surface water propagates relatively fast on bare or poorly vegetated soils. Accordingly, since the 1990s, the rainfall recovery has enhanced the local runoff production and conducts to a dramatic increase of the red flood. The red flood is also well separated in time from the Guinean flood, exceeds it and has reached the highest level ever recorded. Climate variability with its consequences on the rainfall regime and LULC changes have both played a role, in turn, in the recent flood risk increase in Niamey. Whether climate/rainfall variability or LULC is the dominant factor depends on the period considered.

This study sheds more light on the temporality of the different drivers role, compared to previous studies (Seguis et al., 2004; D'Orgeval and Polcher, 2008; Aich et al., 2015).

More work could be done to analyse the exact timing of the changes. The model used here is relatively coarse in resolution, the physics is simplified and does not represent all the complexity of the vegetation-hydrology interaction. Uncertainty in the rainfall forcing and the discharge data is also limiting. Further efforts should be made to understand the role of rainfall in the recent increase of the red flood intensity. Have some specific changes in the rainfall regime contributed to the increased flood risk (increase in the frequency or intensity of extreme events, changes in the dry/wet spells, etc.)? High-resolution rainfall products, models and LULC change maps are needed to investigate these questions at the relevant scales. Effort should also be made to better understand the drainage area changes and integrate a more realistic representation of the temporary rivers (Koris) and of the endorheic areas in the hydrological modelling.

\section{Data availability}

Several data sets have been used in this paper, none of these data sets are currently attached to a DOI. The global rainfall data sets from CPC and from the PERSIANN-CDR project can be downloaded from their respective websites: 
- http://ftp.cpc.ncep.noaa.gov/precip/CPC_UNI_PRCP/ GAUGE_GLB/

- https://www.ncdc.noaa.gov/cdr/atmospheric/ precipitation-persiann-cdr.

The data used by LTHE to provide the KRIG product is the property of the national weather services from Mali, Burkina Faso and Niger; information and contact names can be requested through Guillaume Quantin from LTHE, who processed the data (guillaume.quantin@ird.fr). The AMMACATCH data (KRIG dense product, see Appendix A) can be requested through the AMMA-CATCH data base (http://bd. amma-catch.org/amma-catch2/main.jsf). The discharge data can be requested through the Autorite du Bassin du Niger website (http://www.abn.ne/) or by contacting the ABN data base coordinator and co-author of the paper: Bachir Alkali Tanimoun (balkaly@abn.ne). 


\section{Appendix A: Rainfall products analysis}

The three long-term rainfall data sets used in the present study have been evaluated against a dense network of gauges. The network is one of the three instrumented sites of the AMMA-CATCH observatory system (African Monsoon Multidisciplinary Analysis - CATCH stands for Couplage de l'Atmosphère Tropicale et du Cycle Hydrologique in French; Lebel et al., 2010). It is located in the region of Niamey. The site covers an area of $1^{\circ} \times 1^{\circ}\left(\right.$ centred at $2.5^{\circ} \mathrm{E}$ and $\left.13.5^{\circ} \mathrm{N}\right)$ and has monitored the rainfall since 1990 with a dense gauge network (between 40 and 50 gauges). This high-resolution network was already used as a reference to compare and validate satellite rainfall products (Roca et al., 2010; Gosset et al., 2013; Kirstetter et al., 2012). The rain gauges produce $5 \mathrm{~min}$ punctual rainfall series, which are interpolated to a $0.25^{\circ} 3 \mathrm{~h}$ grid by Lagrangian kriging (Vischel et al., 2011). This ground reference is referred to as KRIG DENSE hereafter.
Figure A1 compares the three rainfall estimates and the ground reference KRIG DENSE. The comparison is carried out on four pixels of $0.5^{\circ}$ at a daily time step between 1990 and 2012 for the rainiest months (June, July, August and September). The inter-annual series of rainfall accumulation is satisfactory for all three products, but KRIG is closer to the reference $\left(r^{2}=0.85\right)$ than PERSIANN-CDR $\left(r^{2}=0.7\right)$ and CPC $\left(r^{2}=0.68\right)$. KRIG and PERSIANN-CDR tend to smooth the rainfall fields in time, with a low daily conditional mean rainfall (Fig. A1b) and a lot of rainy days (Fig. A1c). Both KRIG and PERSIANN-CDR reproduce well the rainfall extension seen by the reference between 1990 and 2005 although KRIG overestimates the spatial extension in the last 5 years (this is attributed to the reduced number of gauges in the network). CPC follows the tendency observed with the reference but has the greatest inter-annual variability and tends to underestimate the rainfall events extension. As already highlighted in several studies (Roca et al., 2010; Gosset et al., 2013; Casse et al., 2015), rainfall products with similar annual rainfall accumulation may exhibit large differences in the spatial, temporal and intensity distribution of rainfall. These differences impact the hydrological simulations (Casse et al., 2015). (a) Annual rainfall

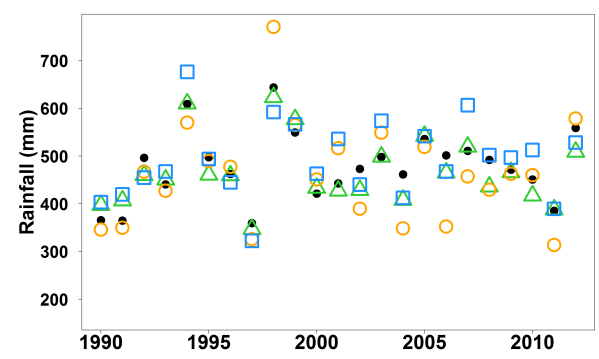

(b) Mean conditional daily rainfall

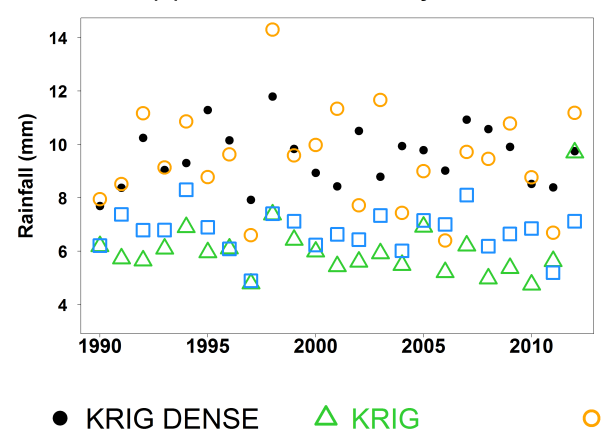

(c) Rainy days

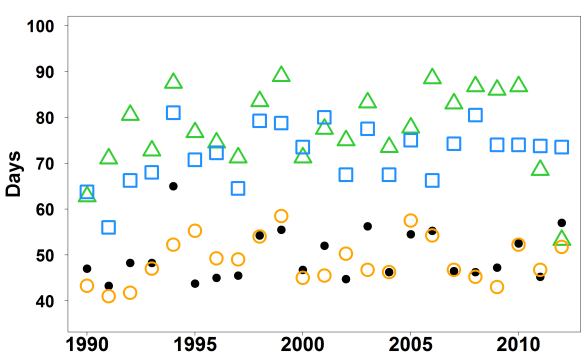

(d) Daily rainfall extension

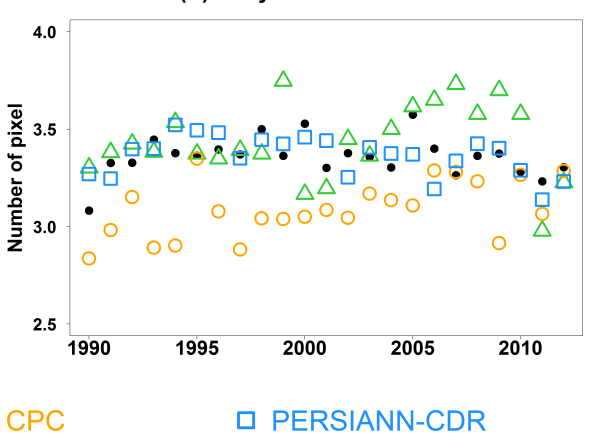

Figure A1. Annual (JJAS) series of rainfall characteristics between 1990 and 2012 computed for the reference (KRIG-DENCE, black dots) and the three tested products: KRIG (open green triangle), CPC (open orange circle) and PERSIANN-CDR (open blue square). (a) mean annual rainfall amount series, (b) annual number of rainy day, (c) mean conditional daily rainfall series and (d) mean of rain extension over the studied area (in pixel). 
Acknowledgements. We warmly thank the Niger Basin Authority (ABN), for providing the Niger River discharge data and for their collaboration. We would like also to thank all the teams that provided the various rainfall data sets online. We also are grateful to L. Gal for her precious help and advice for the maps. This work has been co-funded by the French Centre National d'Etudes spatiales (CNES) and the Midi-Pyrénées region. It was also partly supported by the French national programme EC2CO-LEFE "Evolution récente de l'aléa hydro-climatique au Sahel: détection et éléments d'attribution".

Edited by: R. Uijlenhoet

Reviewed by: N. Wanders and one anonymous referee

\section{References}

Aich, V., Liersch, S., Vetter, T., Andersson, J., Müller, E., and Hattermann, F.: Climate or Land Use? - Attribution of Changes in River Flooding in the Sahel Zone, Water, 7, 2796-2820, doi:10.3390/w7062796, 2015.

Albergel, J.: Sécheresse, désertification et ressources en eau de surface - Application aux petits bassins du Burkina Faso, in: The Influence of Climate Change and Climatic Variability on the Hydrologic Regime and Water Resources, vol. 168, 355-365, IAHS PUBLICATION, Vancouver, 1987.

Amani, A. and Nguetora, M.: Evidence d'une modification du régime hydrologique du fleuve Niger à Niamey, in 4th FRIEND 2002 - Regional Hydrology?: Bridging the Gap between Research and practice, vol. 274, 449-456, IAHS PUBLICATION, Cape Town, South Africa, 2002.

AMMA-CATCH database, available at: http://bd.amma-catch.org/ amma-catch2/main.jsf, last access: 7 July 2016.

Amogu, O., Descroix, L., Yéro, K. S., Le Breton, E., Mamadou, I., Ali, A., Vischel, T., Bader, J.-C., Moussa, I. B., Gautier, E., Boubkraoui, S., and Belleudy, P.: Increasing River Flows in the Sahel?, Water, 2, 170-199, doi:10.3390/w2020170, 2010.

Ashouri, H., Hsu, K.-L., Sorooshian, S., Braithwaite, D. K., Knapp, K. R., Cecil, L. D., Nelson, B. R., and Prat, O. P.: PERSIANNCDR: Daily Precipitation Climate Data Record from Multisatellite Observations for Hydrological and Climate Studies, B. Am. Meteorol. Soc., 96, 69-83, doi:10.1175/BAMS-D-13-00068.1, 2015.

Boone, A., Calvet, J.-C., and Noilhan, J.: Inclusion of a third soil layer in a land surface scheme using the force-restore method, J. Appl. Meteorol., 38, 1611-1630, 1999.

Briquet, J. P., Mahé, G., Bamba, F., and Olivry, J. C.: Changements climatiques recents et modification du regime hydrologique du fleuve Niger Koulikoro (Mali), in: L'hydrologie tropicale?: géoscience et outil pour le développement, vol. 238, 157-166, IAHS PUBLICATION, Paris, 1996

Camberlin, P., Beltrando, G., Fontaine, B., and Richard, Y.: Pluviométrie et crises climatiques en Afrique Tropicale?: changements durables ou fluctuations interannuelles?, Histoire et Géographes, 379, 263-273, 2002.

Casenave, A. and Valentin, C.: A runoff capability classification system based on surface features criteria in semi-arid areas of West Africa, J. Hydrol., 130, 231-249, 1992.
Casse, C. and Gosset, M.: Analysis of hydrological changes and flood increase in Niamey based on the PERSIANN-CDR satellite rainfall estimate and hydrological simulations over the 19832013 period, Proc. IAHS, 370, 117-123, doi:10.5194/piahs-370117-2015, 2015.

Casse, C., Gosset, M., Peugeot, C., Pedinotti, V., Boone, A., Tanimoun, B. A., and Decharme, B.: Potential of satellite rainfall products to predict Niger River flood events in Niamey, Atmos. Res., 163, 162-176, doi:10.1016/j.atmosres.2015.01.010, 2015.

Chen, M., Shi, W., Xie, P., Silva, V. B. S., Kousky, V. E., Wayne Higgins, R., and Janowiak, J. E.: Assessing objective techniques for gauge-based analyses of global daily precipitation, J. Geophys. Res., 113, D04110, doi:10.1029/2007JD009132, 2008.

Climate Prediction Centre (CPC) Gauged-based Analysis of Global Daily Precipitation, available at: http://ftp.cpc.ncep.noaa.gov/ precip/CPC_UNI_PRCP/GAUGE_GLB/, last access: 7 July 2016.

Collinet, J. and Valentin, C.: Analyse des différents facteurs intervenant sur l'hydrodynamique superficielle, Nouvelle perspectives - Applications agronomiques, ORSTOM, Centre d'Adiopodoume, B.P V-51 Abidjan (Côte d'Ivoire), 1979.

Dai, A., Lamb, P. J., Trenberth, K. E., Hulme, M., Jones, P. D., and Xie, P.: The recent Sahel drought is real, Int. J. Climatol., 24, 1323-1331, doi:10.1002/joc.1083, 2004.

Decharme, B. and Douville, H.: Introduction of a sub-grid hydrology in the ISBA land surface model, Clim. Dynam., 26, 65-78, doi:10.1007/s00382-005-0059-7, 2005.

Decharme, B. and Douville, H.: Global validation of the ISBA subgrid hydrology, Clim. Dynam., 29, 21-37, doi:10.1007/s00382006-0216-7, 2007.

Decharme, B., Douville, H., Boone, A., Habets, F., and Noilhan, J.: Impact of an exponential profile of saturated hydraulic conductivity within the ISBA LSM: Simulations over the Rhône basin., J. Hydrometeorol., 7, 61-80, 2006.

Desconnets, J. C., Taupin, J. D., Lebel, T., and Leduc, C.: Hydrology of the HAPEX-Sahel Central Super-site: surface water drainage and aquifer recharge through the pool systems, J. Hydrol., 188-189, 155-178, 1997.

Descroix, L., Mahé, G., Lebel, T., Favreau, G., Galle, S., Gautier, E., Olivry, J.-C., Albergel, J., Amogu, O., Cappelaere, B., Dessouassi, R., Diedhiou, A., Le Breton, E., Mamadou, I., and Sighomnou, D.: Spatio-temporal variability of hydrological regimes around the boundaries between Sahelian and Sudanian areas of West Africa: A synthesis, J. Hydrol., 375, 90-102, doi:10.1016/j.jhydrol.2008.12.012, 2009.

Descroix, L., Genthon, P., Amogu, O., Rajot, J.-L., Sighomnou, D., and Vauclin, M.: Change in Sahelian Rivers hydrograph: The case of recent red floods of the Niger River in the Niamey region, Global Planet. Change, 98-99, 18-30, doi:10.1016/j.gloplacha.2012.07.009, 2012.

Descroix, L., Niang, A. D., Dacosta, H., Panthou, G., Quantin, G., and Diedhiou, A.: Evolution des pluies de cumul élévé et recrudescence des crues depuis 1951 dans le bassin du Niger Moyen (Sahel), Climatologie, 10, 37-50, 2013.

D'Orgeval, T. and Polcher, J.: Impacts of precipitation events and land-use changes on West African river discharges during the years 1951-2000, Clim. Dynam., 31, 249-262, doi:10.1007/s00382-007-0350-x, 2008. 
Eldridge, R. H.: A synoptic study of West African disturbance lines, Q. J. Roy. Meteor. Soc., 83, 303-314, 1957.

Favreau, G., Cappelaere, B., Massuel, S., Leblanc, M., Boucher, M., Boulain, N., and Leduc, C.: Land clearing, climate variability, and water resources increase in semiarid southwest Niger: A review, Water Resour. Res., 45, W00A16, doi:10.1029/2007WR006785, 2009.

Galle, S., Ehrmann, M., and Peugeot, C.: Water balance in a banded vegetation pattern: a case study of tiger bush in western Niger, Catena, 37, 197-216, 1999.

Gandin, L. S.: Objective Analysis of Meteorological Fields. Leningrad, Gidromet; Translated from Russian, Jerusalem, Israel Program for Scientific Translations, 1965, 242 pp., 1965.

Gardelle, J., Hiernaux, P., Kergoat, L., and Grippa, M.: Less rain, more water in ponds: a remote sensing study of the dynamics of surface waters from 1950 to present in pastoral Sahel (Gourma region, Mali), Hydrol. Earth Syst. Sci., 14, 309-324, doi:10.5194/hess-14-309-2010, 2010.

Gosset, M., Viarre, J., Quantin, G., and Alcoba, M.: Evaluation of several rainfall products used for hydrological applications over West Africa using two high-resolution gauge networks, Q. J. Roy. Meteor. Soc., 139, 923-940, doi:10.1002/qj.2130, 2013.

Hiernaux, P. and Le Houérou, H. N.: Les parcours du Sahel, Sécheresse, 17, 51-71, 2006.

Houze, R. A.: Cloud dynamics, International Geophysics Series, 53, Academic Press Inc., San Diego, 1993.

Huffman, G. J., Alder, R. F., Arkin, P., Chang, A., Ferraro, R., Gruber, A., Janowiak, J., McNab, A., Rudolf, B., and Schneider, U.: The Global Precipitation Climatology Project (GPCP) Combined Precipitation Dataset, B. Am. Meteorol. Soc., 78, 5-20, 1997.

Huffman, G. J., Adler, R. F., Bolvin, D. T., and Gu, G.: Improving the global precipitation record: GPCP Version 2.1, Geophys. Res. Lett., 36, L17808, doi:10.1029/2009GL040000, 2009.

Kirstetter, P.-E., Viltard, N., and Gosset, M.: An error model for instantaneous satellite rainfall estimates: evaluation of BRAINTMI over West Africa, Q. J. Roy. Meteor. Soc., 139, 894-911, doi:10.1002/qj.1964, 2012.

Lamb, P. J.: Persistence of Subsaharan drough, Nature, 299, 46-48, 1982.

Laurent, H., d'Amato, N., and Lebel, T.: How important is the contribution of the mesoscale convective complexes to the Sahelian rainfall?, Phys. Chem. Earth, 23, 629-633, 1998.

Le Barbé, L. and Lebel, T.: Rainfall climatology of the HAPEXSahel region during the years 1950-1990, J. Hydrol., 188-189, 43-73, 1997.

Le Barbé, L., Lebel, T. and Tapsoba, D.: Rainfall variability in West Africa during the years 1950-90, J. Climate., 15, 187-202, 2002.

Lebel, T. and Ali, A.: Recent trends in the Central and Western Sahel rainfall regime (1990-2007), J. Hydrol., 375, 52-64, doi:10.1016/j.jhydrol.2008.11.030, 2009.

Lebel, T., Diedhiou, A., and Laurent, H.: Seasonal cycle and interannual variability of the Sahelian rainfall at hydrological scales, J. Geophys. Res., 108, 8389, doi:10.1029/2001JD001580, 2003.

Lebel, T., Parker, D. J., Flamant, C., Bourlès, B., Marticorena, B., Mougin, E., Peugeot, C., Diedhiou, A., Haywood, J. M., Ngamini, J. B., Polcher, J., Redelsperger, J.-L., and Thorncroft, C. D.: The AMMA field campaigns: multiscale and multidisciplinary observations in the West African region, Q. J. Roy. Meteor. Soc., 136, 8-33, doi:10.1002/qj.486, 2010.
Leblanc, M. J., Favreau, G., Massuel, S., Tweed, S. O., Loireau, M., and Cappelaere, B.: Land clearance and hydrological change in the Sahel: SW Niger, Global Planet. Change, 61, 135-150, doi:10.1016/j.gloplacha.2007.08.011, 2008.

Leduc, C., Favreau, G., and Schroeter, P.: Long-term rise in a Sahelian water-table: The Continental Terminal in south-west Niger, J. Hydrol., 243, 43-54, 2001.

L'Hote, Y., Mahé, G., Somé, B., and Triboulet, J. P.: Analysis of a Sahelian annual rainfall index from 1896 to 2000; the drought continues, Hydrolog. Sci. J., 47, 563-572, 2002.

Mahé, G.: Surface/groundwater interactions in the Bani and Nakambe rivers, tributaries of the Niger and Volta basins, West Africa, Hydrolog. Sci. J., 54, 704-712, doi:10.1623/hysj.54.4.704, 2009.

Mahé, G. and Paturel, J.-E.: 1896-2006 Sahelian annual rainfall variability and runoff increase of Sahelian Rivers, Comptes Rendus Geoscience, 341, 538-546, doi:10.1016/j.crte.2009.05.002, 2009.

Mahé, G., Olivry, J.-C., Dessouassi, R., Orange, D., Bamba, F., and Servat, E.: Relations eaux de surface - eaux souterraines d'une rivière tropicale au Mali, Comptes Rendus de l'Académie des Sciences-Series IIA-Earth and Planetary Science, 330, 689-692, 2000.

Mahé, G., Leduc, C., Amani, A., Paturel, J. E., Girard, S., Servat, E., and Dezetter, A.: Augmentation récente du ruissellement de surface en région soudano-sahélienne et impact sur les ressources en eau, in Hydrology of the Mediterranean and Semiarid Region, vol. 278, 215-222, IAHS PUBLICATION, Montpellier, 2003.

Mahé, G., Paturel, J.-E., Servat, E., Conway, D., and Dezetter, A.: The impact of land use change on soil water holding capacity and river flow modelling in the Nakambe River, Burkina-Faso, J. Hydrol., 300, 33-43, doi:10.1016/j.jhydrol.2004.04.028, 2005.

Mamadou, I., Gautier, E., Descroix, L., Noma, I., Bouzou Moussa, I., Faran Maiga, O., Genthon, P., Amogu, O., Malam Abdou, M., and Vandervaere, J.-P.: Exorheism growth as an explanation of increasing flooding in the Sahel, Catena, 131, 130-139, doi:10.1016/j.catena.2015.03.017, 2015.

Masson, V., Champeaux, J.-L., Chauvin, F., Meriguet, C., and Lacaze, R.: A global database of land surface parameters at $1-\mathrm{km}$ resolution in meteorological and climate models, J. Climate, 16, 1261-1282, 2003.

Masson, V., Le Moigne, P., Martin, E., Faroux, S., Alias, A., Alkama, R., Belamari, S., Barbu, A., Boone, A., Bouyssel, F., Brousseau, P., Brun, E., Calvet, J.-C., Carrer, D., Decharme, B., Delire, C., Donier, S., Essaouini, K., Gibelin, A.-L., Giordani, H., Habets, F., Jidane, M., Kerdraon, G., Kourzeneva, E., Lafaysse, M., Lafont, S., Lebeaupin Brossier, C., Lemonsu, A., Mahfouf, J.-F., Marguinaud, P., Mokhtari, M., Morin, S., Pigeon, G., Salgado, R., Seity, Y., Taillefer, F., Tanguy, G., Tulet, P., Vincendon, B., Vionnet, V., and Voldoire, A.: The SURFEXv7.2 land and ocean surface platform for coupled or offline simulation of earth surface variables and fluxes, Geosci. Model Dev., 6, 929-960, doi:10.5194/gmd-6-929-2013, 2013.

Mathon, V., Laurent, H., and Lebel, T.: Mesoscale convective system rainfall in the Sahel, J. Appl. Meteorol., 41, 1081-1092, 2002.

Millot, J. A.: Les crues du Niger, Annales de Géographie, 22, 6893, doi:10.3406/geo.1913.8385, 1913. 
Narisma, G. T., Foley, J. A., Licker, R., and Ramankutty, N.: Abrupt changes in rainfall during the twentieth century, Geophys. Res. Lett., 34, L06710, doi:10.1029/2006GL028628, 2007.

Nicholson, S. E., Some, B., and Kone, B.: An analysis of recent rainfall conditions in West Africa, including the rainy seasons of the 1997 El Niño and the 1998 La Niña years, J. Climate, 13, 2628-2640, 2000.

Nka, B. N., Oudin, L., Karambiri, H., Paturel, J. E., and Ribstein, P.: Trends in floods in West Africa: analysis based on 11 catchments in the region, Hydrol. Earth Syst. Sci., 19, 4707-4719, doi:10.5194/hess-19-4707-2015, 2015.

Noilhan, J. and Planton, S.: A Simple Parametrization of Land Surface Processes for Meteorological Models, Mon. Weather Rev., 117, 536-549, doi:10.1175/15200493(1989)117<0536:ASPOLS>2.0.CO;2, 1989.

Panthou, G., Vischel, T., and Lebel, T.: Recent trends in the regime of extreme rainfall in the Central Sahel, Int. J. Climatol., 34, 3998-4006, doi:10.1002/joc.3984, 2014.

Paturel, J.-E., Diawara, A., Kong, A., Siou, L., Talin, E., Ferry, L., Mahé, G., Dezetter, A., Muther, N., Martin, D., Rouche, N., L'Aour-Cres, A., Seguis, L., Coulibaly, N., Bahire-Kone, S., and Koite, M.: Caractérisation de la sécheresse hydropluviométrique du Bani, principal affluent du fleuve Niger au Mali, in: Global Change: Facing Risks and Threats to Water Resources, IAHS PUBLICATION, 661-667, Fez, 2010.

Pedinotti, V., Boone, A., Decharme, B., Crétaux, J. F., Mognard, N., Panthou, G., Papa, F., and Tanimoun, B. A.: Evaluation of the ISBA-TRIP continental hydrologic system over the Niger basin using in situ and satellite derived datasets, Hydrol. Earth Syst. Sci., 16, 1745-1773, doi:10.5194/hess-16-1745-2012, 2012.

PERSIANN Precipitation Climate Data Record, available at:https://www.ncdc.noaa.gov/cdr/atmospheric/ precipitation-persiann-cdr, last access: 7 July 2016.

Peltier, R., Bertrand, A., Lawali, E. M., Madon, G., and Montagne, P.: Marchés ruraux de bois-énergie ay Sahel, Bois et Forêts des Tropiques, 245, 3ème Trimestre, 1995.

Pradé, M.: Fleuves et rivières, Les Études rhodaniennes, 10, 97$100,1934$.

Roca, R., Chambon, P., Jobard, I., Kirstetter, P.-E., Gosset, M., and Bergès, J.-C.: Comparing Satellite and Surface Rainfall Products over West Africa at Meteorologically Relevant Scales during the AMMA Campaign Using Error Estimates, J. Appl. Meteorol. Clim., 49, 715-731, doi:10.1175/2009JAMC2318.1, 2010.

Rowell, D. P. and Milford, J. R.: On the Generation of African Squall Lines, J. Climate, 6, 1181-1193, 1993.
Seghieri, J., Galle, S., and Rajot, J. L.: La brousse tigrée dans le Sahel Nigérien?: étude de la cofluctuation du stock hydrique et de la végétation annuelle, $\mathrm{X}^{e}$ journées hydrologiques, 123-141, ORSTOM, 1994.

Seguis, L., Cappelaere, B., Milesi, G., Peugeot, C., Massuel, S., and Favreau, G.: Simulated impacts of climate change and landclearing on runoff from a small Sahelian catchment, Hydrol. Process., 18, 3401-3413, 2004.

Sighomnou, D., Descroix, L., Mahe, G., Moussa, I. B., Gautier, E., Mamadou, I., Vandervaere, J.-P., Bachir, T., Coulibaly, B., Rajot, J.-L., Issa, O. M., Dessay, N., Delaître, E., Maiga, O. F., Diedhiou, A., Panthou, G., Vischel, T., Yacouba, H., Karambiri, H., Paturel, J. E., Diello, P., Mougin, E., Kergoat, L., and Hiernaux, P.: La crue de 2012 à Niamey?: un paroxysme du paradoxe du Sahel?, Sécheresse, 24, 3-13, doi:10.1684/sec.2013.0370, 2013.

Sorooshian, S., Hsu, K., Gao, X., Gupta, H. V., Imam, B., and Braithwaite, D.: Evaluation of PERSIANN System SatelliteBased Estimates of Tropical Rainfall, B. Am. Meteorol. Soc., 81, 2035-2046, 2000.

Valentin, C., Rajot, J.-L., and Mitja, D.: Responses of soil crusting, runoff and erosion to fallowing in the sub-humid and semi-arid regions of West Africa, Agr. Ecosyst. Environ., 104, 287-302, doi:10.1016/j.agee.2004.01.035, 2004.

Vischel, T. and Lebel, T.: Assessing the water balance in the Sahel: Impact of small scale rainfall variability on runoff. Part 2: Idealized modeling of runoff sensitivity, J. Hydrol., 333, 340-355, doi:10.1016/j.jhydrol.2006.09.007, 2007.

Vischel, T., Quantin, G., Lebel, T., Viarre, J., Gosset, M., Cazenave, F., and Panthou, G.: Generation of High-Resolution Rain Fields in West Africa: Evaluation of Dynamic Interpolation Methods, J. Hydrometeorol., 12, 1465-1482, doi:10.1175/JHM-D-1005015.1, 2011

Weedon, G. P., Gomes, S., Viterbo, P., Shuttleworth, W. J., Blyth, E., Österle, H., Adam, J. C., Bellouin, N., Boucher, O., and Best, M.: Creation of the WATCH Forcing Data and Its Use to Assess Global and Regional Reference Crop Evaporation over Land during the Twentieth Century, J. Hydrometeorol., 12, 823-848, doi:10.1175/2011JHM1369.1, 2011.

Weedon, G. P., Balsamo, G., Bellouin, N., Gomes, S., Best, M. J., and Viterbo, P.: The WFDEI meteorological forcing data set: WATCH Forcing Data methodology applied to ERAInterim reanalysis data, Water Resour. Res., 50, 7505-7514, doi:10.1002/2014WR015638, 2014. 